nol

MLDI-MHA-74-62-0028

FOR REFERENEE NOT TO BE TAKEN

FROA THIS ROOM

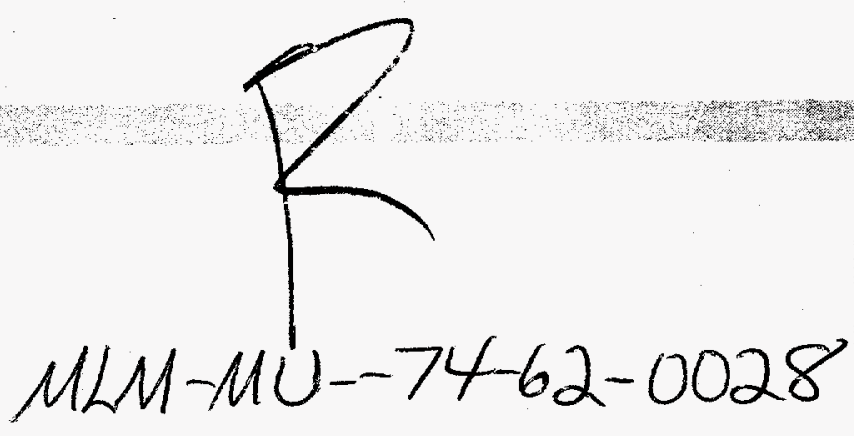

CAPABILITIES AND RESOURCES FOR TRITIUM RESEARCH AND DEVELOPMENT

\section{February 7, 1974}

\author{
RECEIVED \\ JUL 011996 \\ OSTI
}

FOR REFERENCE NOT TO BE TAKEN FROH THIS ROOM

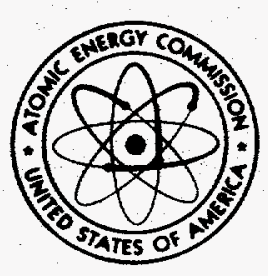

- Monsanto

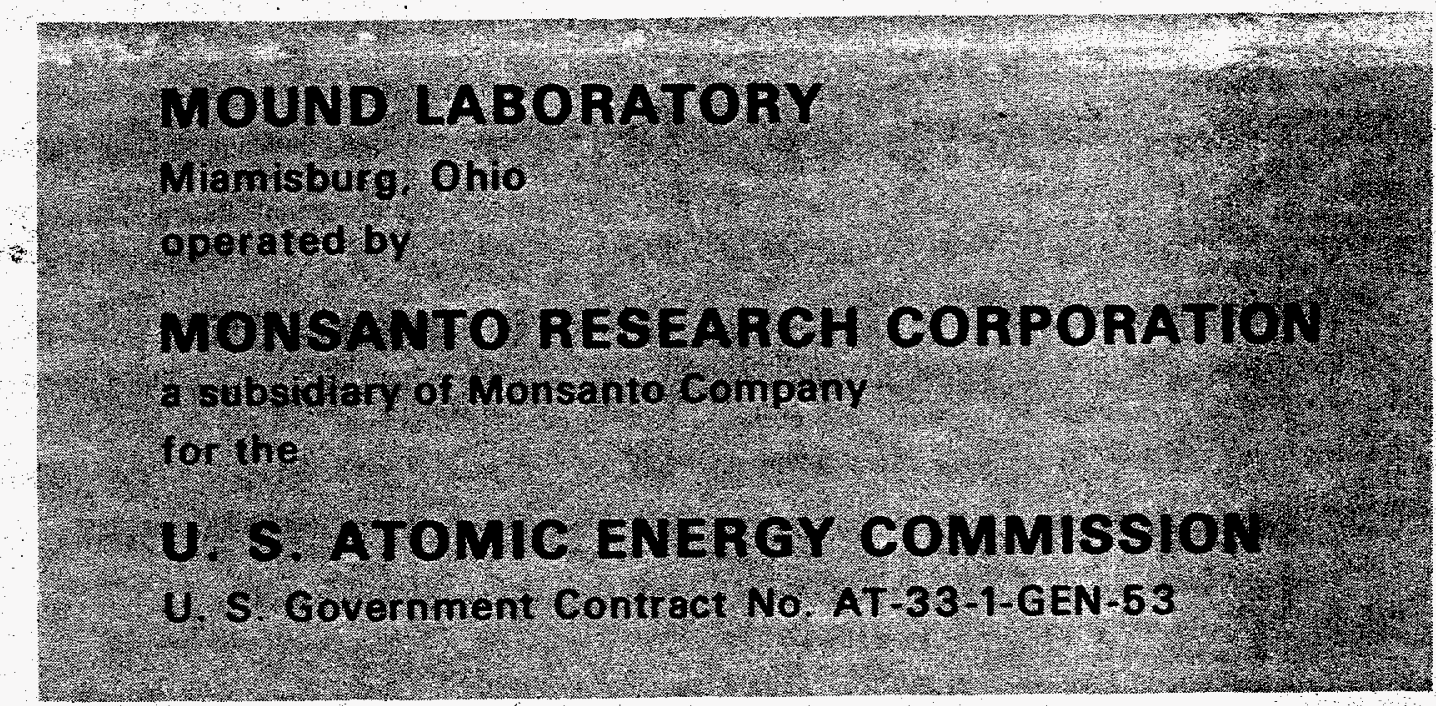




\section{DISCLAIMER}

Portions of this document may be illegible in electronic image products. Images are produced from the best available original document. 


\title{
Capabilities and Resources for Tritium Research and Development
}

\author{
Excerpts from a Presentation
}

by Mound Laboratory at AEC Headquarters

February 7, 1974

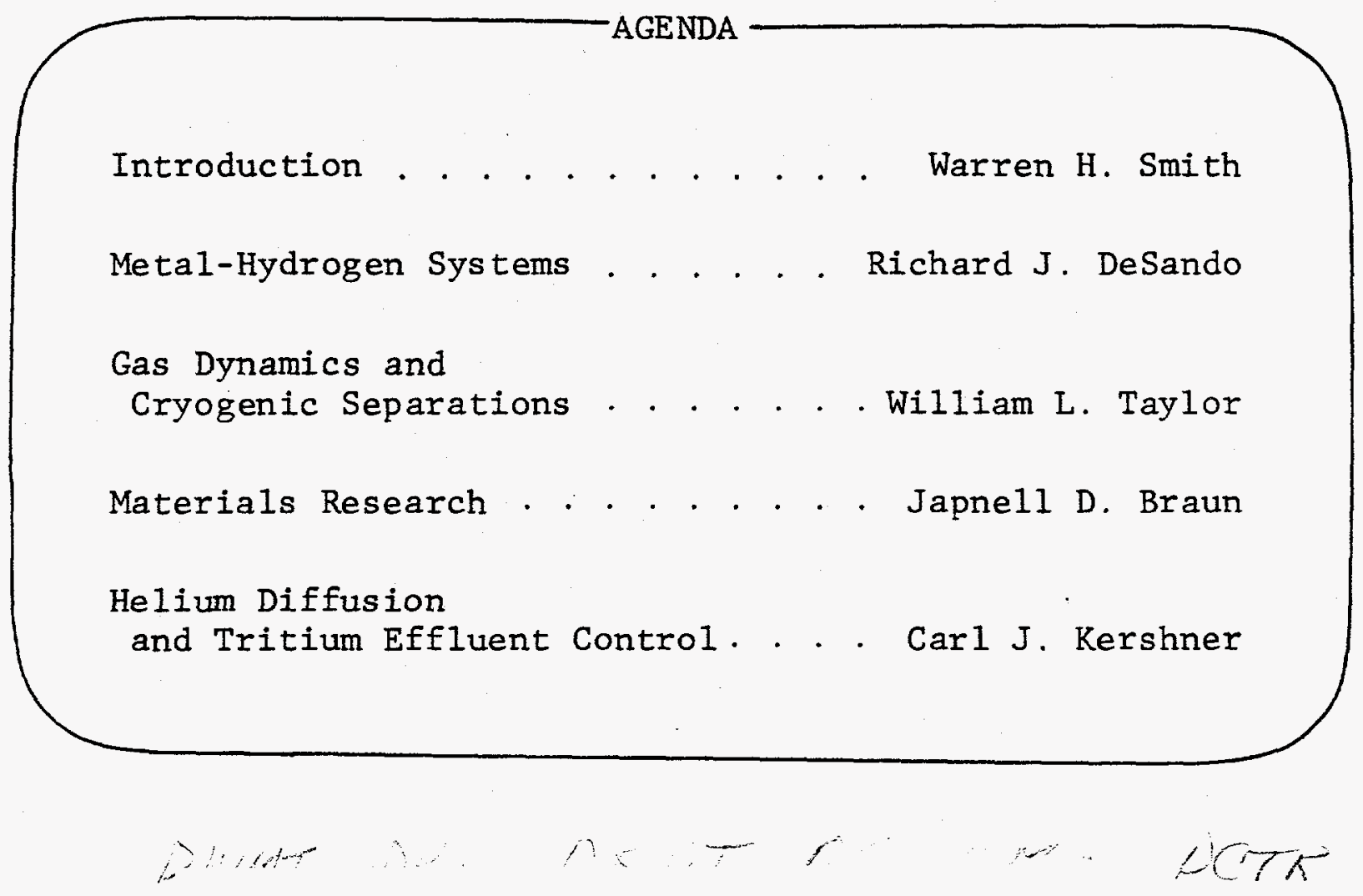

DISCLAIMER

This report was prepared as an account of work sponsored by an agency of the United States Government. Neither the United States Government nor any agency thereof, nor any of their employees, makes any warranty, express or implied, or assumes any legal liability or responsibility for the accuracy, completeness, or usefulness of any information, apparatus, product, or process disclosed, or represents that its use would not infringe privately owned rights. Reference herein to any specific commercial product, process, or service by trade name, trademark, manufacturer, or otherwise does not necessarily constitute or imply its endorsement, recommendation, or favoring by the United States Government or any agency thereof. The views and opinions of authors expressed herein do not necessarily state or reflect those of the United States Government or any agency thereof. 


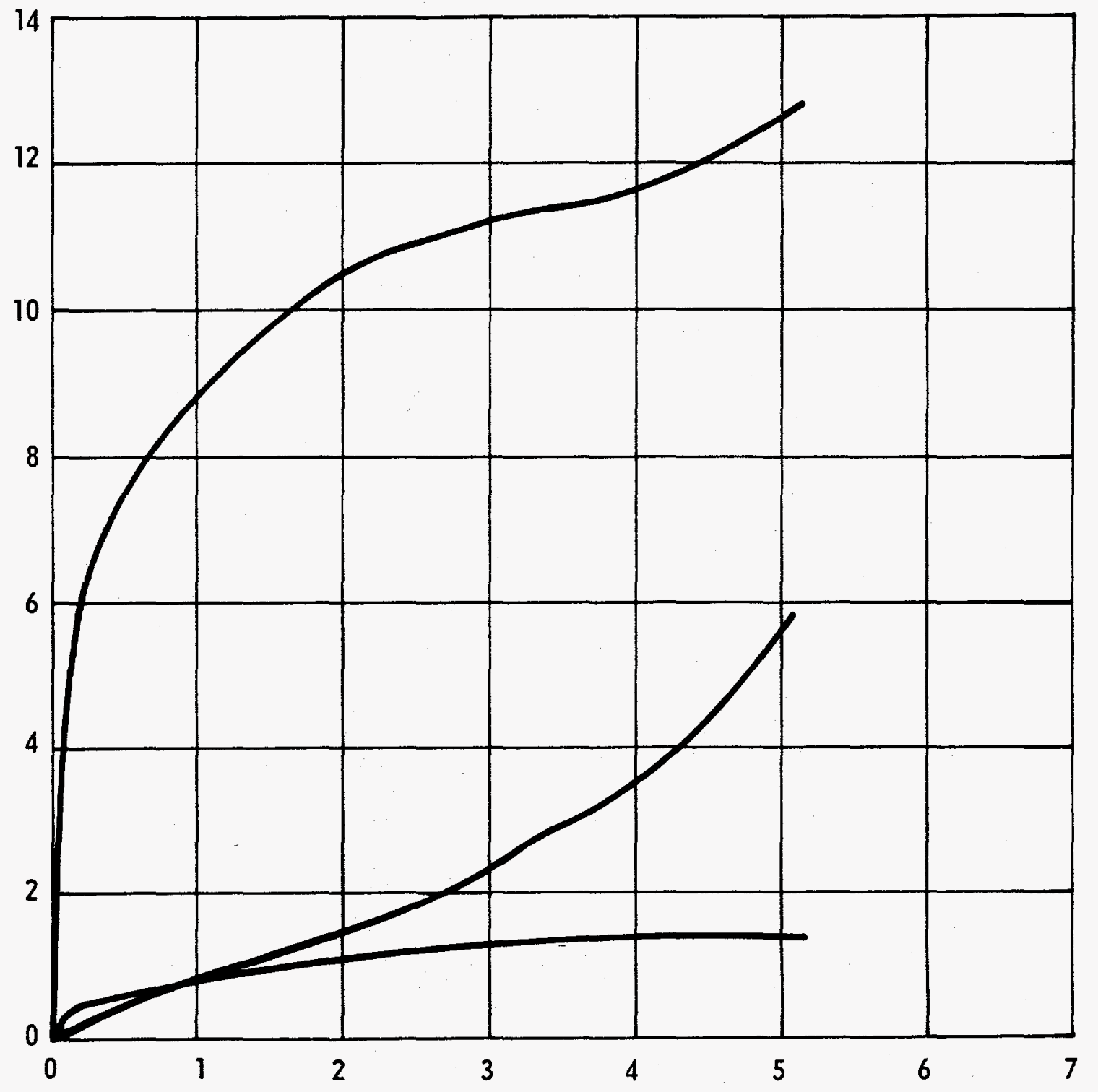




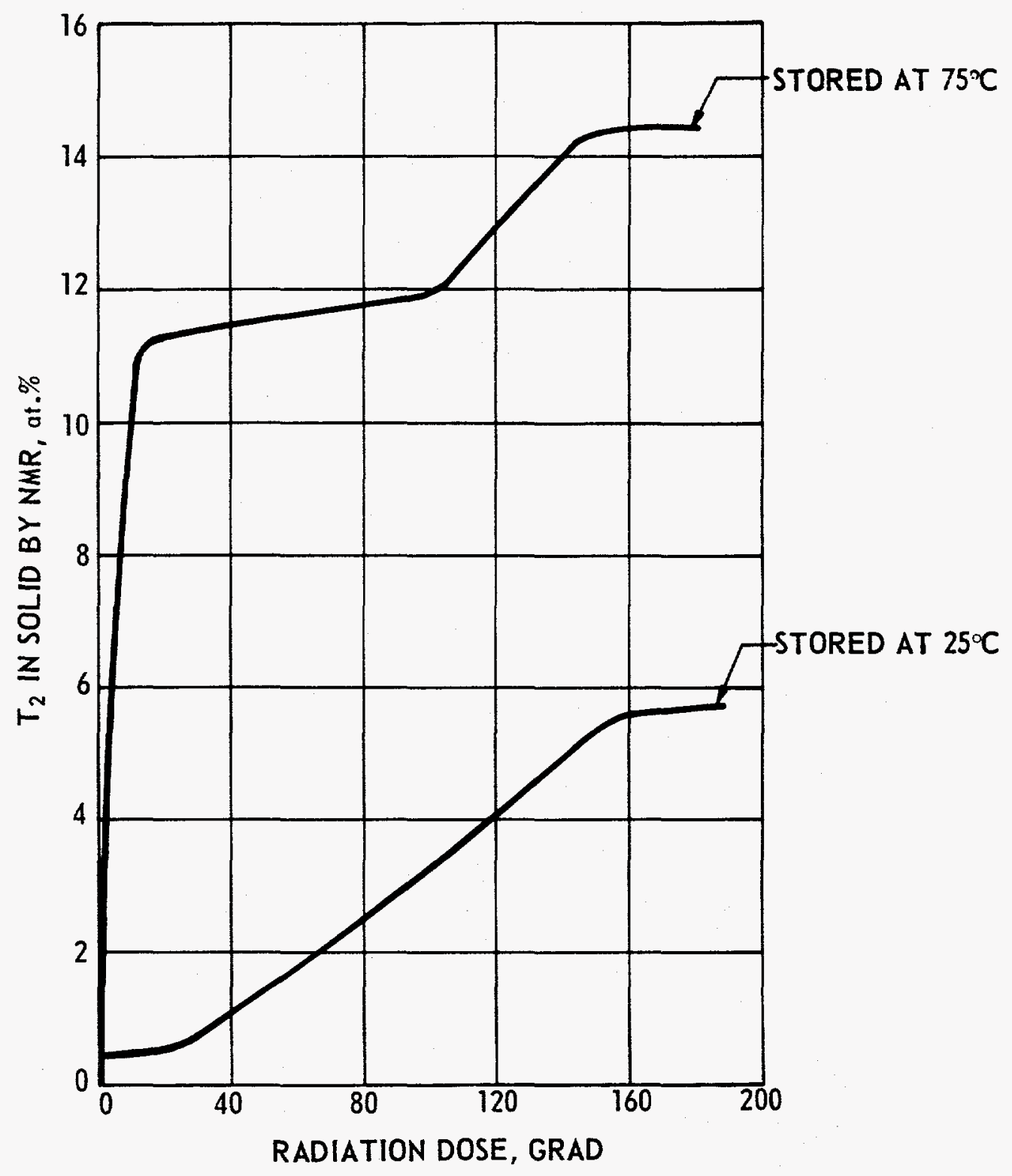




\section{F - CENTER CONCENTRATION AS INDICATED BY EPR}

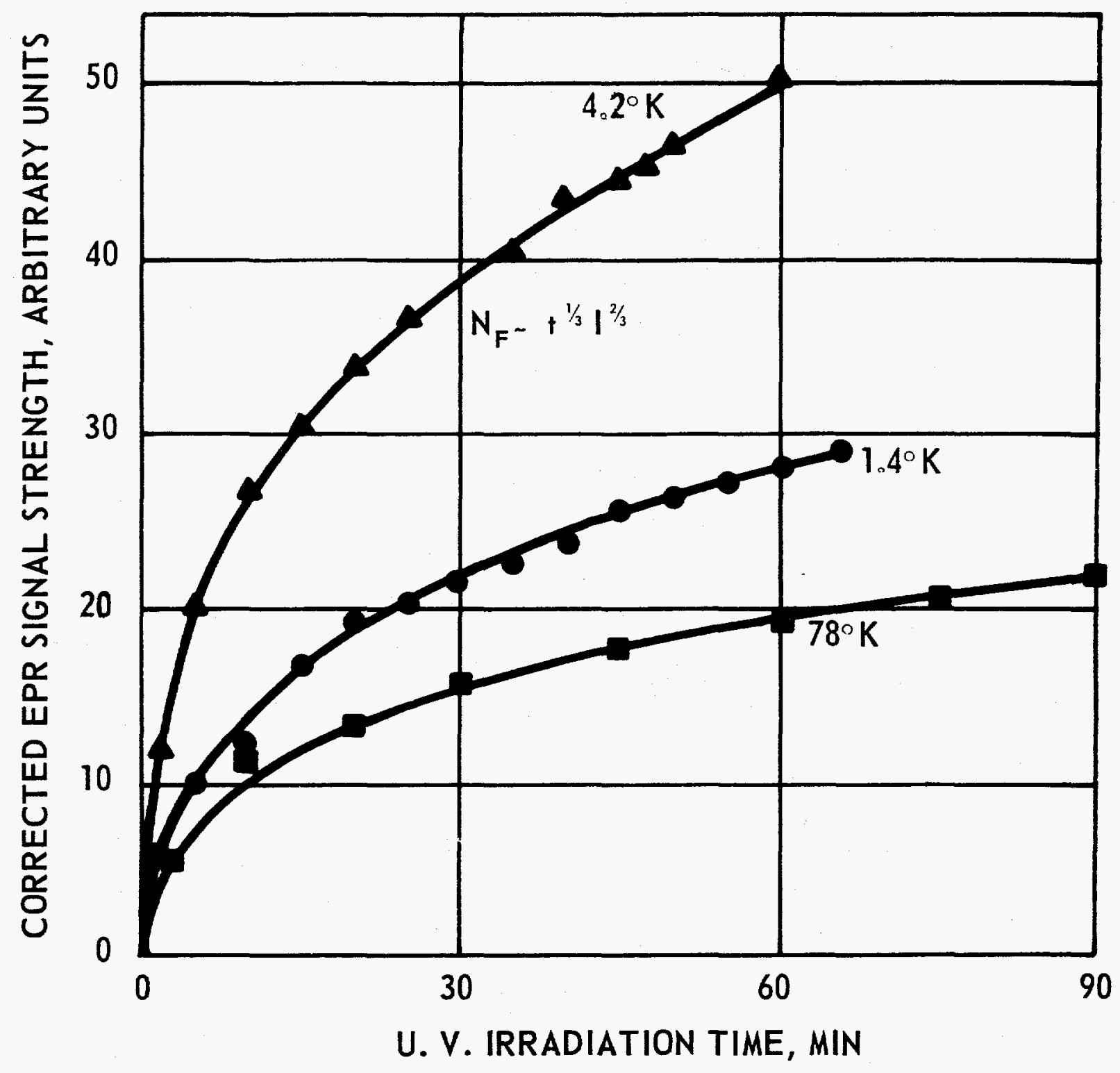




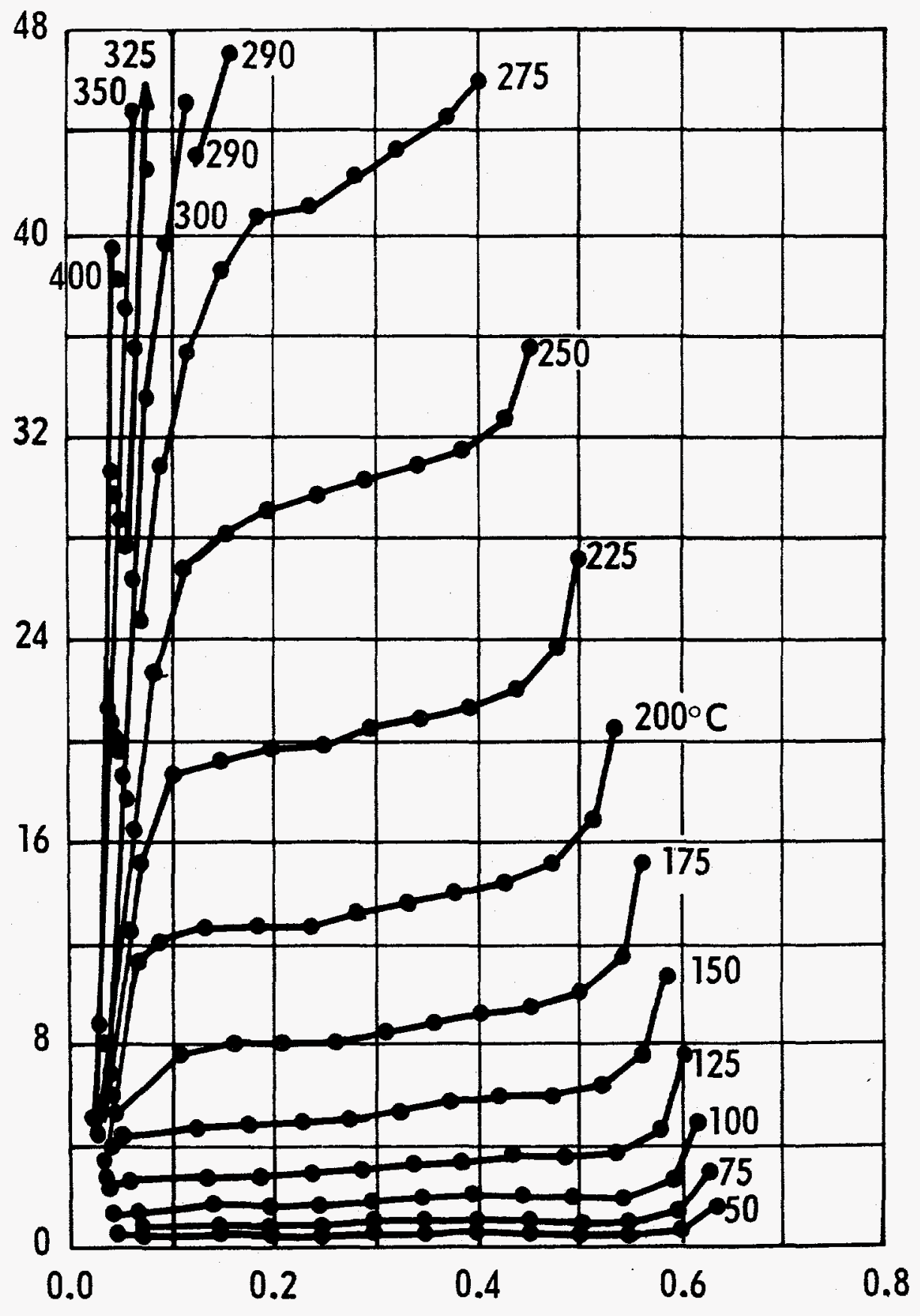


ISOTHERMS, $200^{\circ} \mathrm{C}$

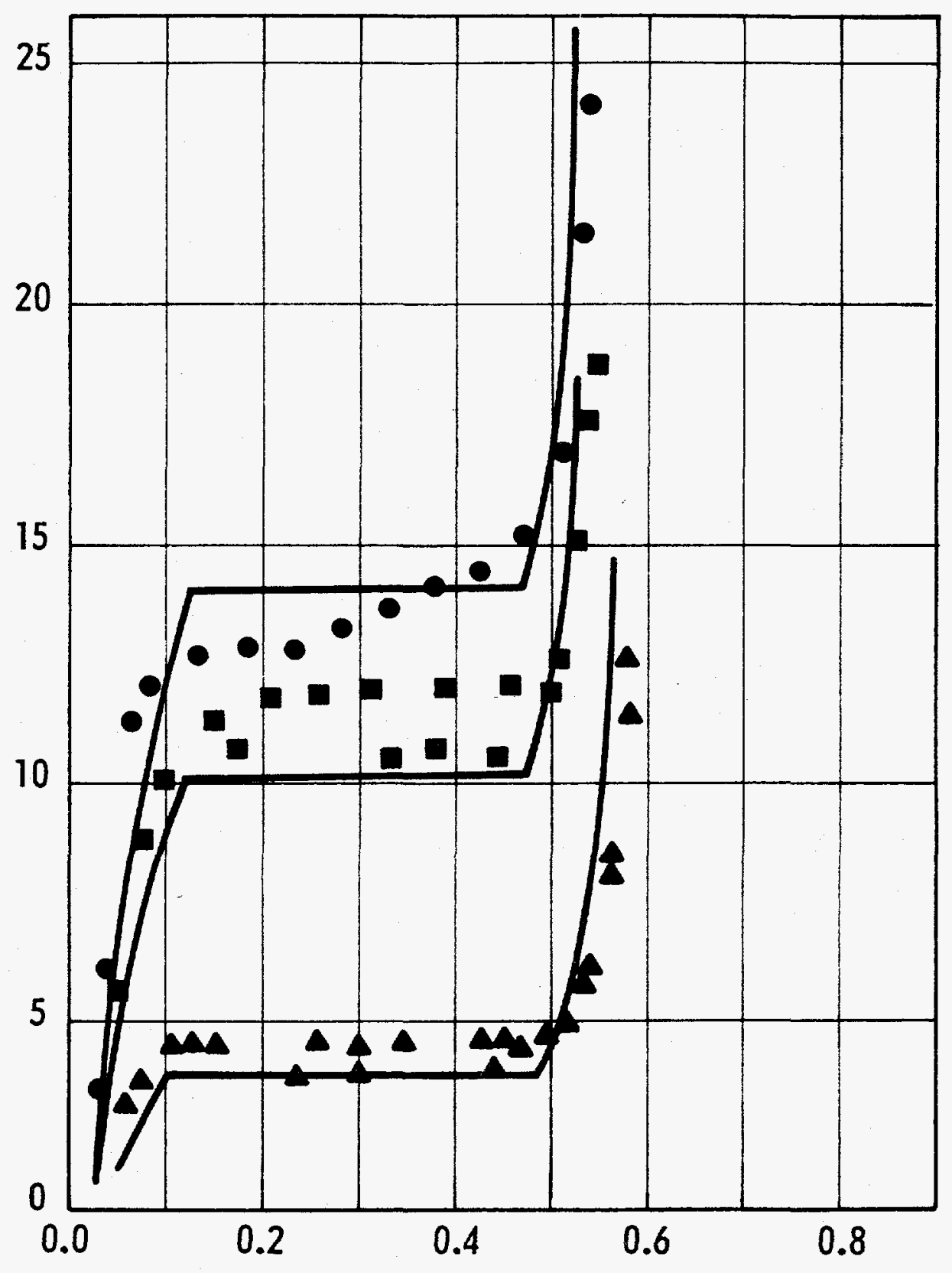




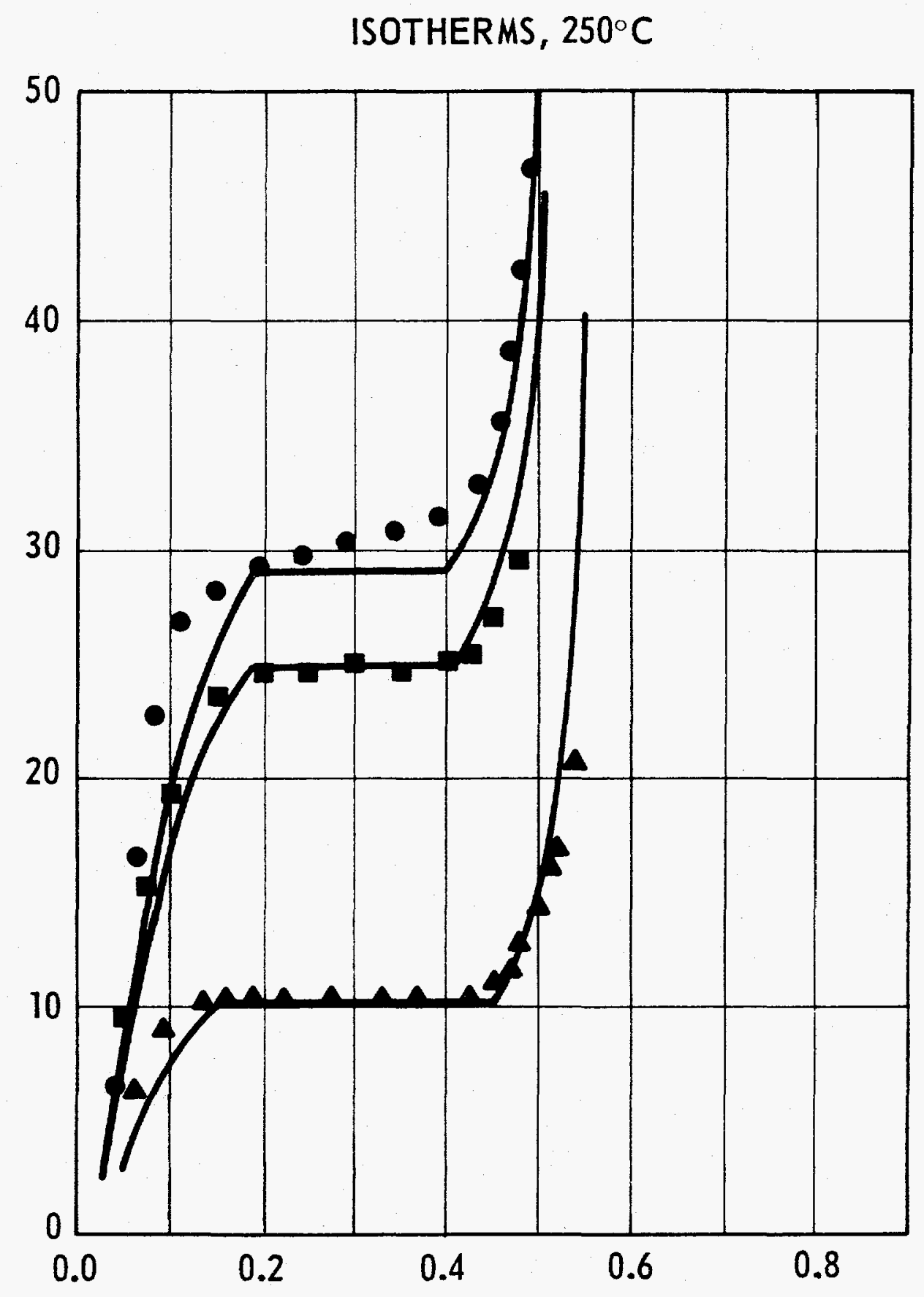




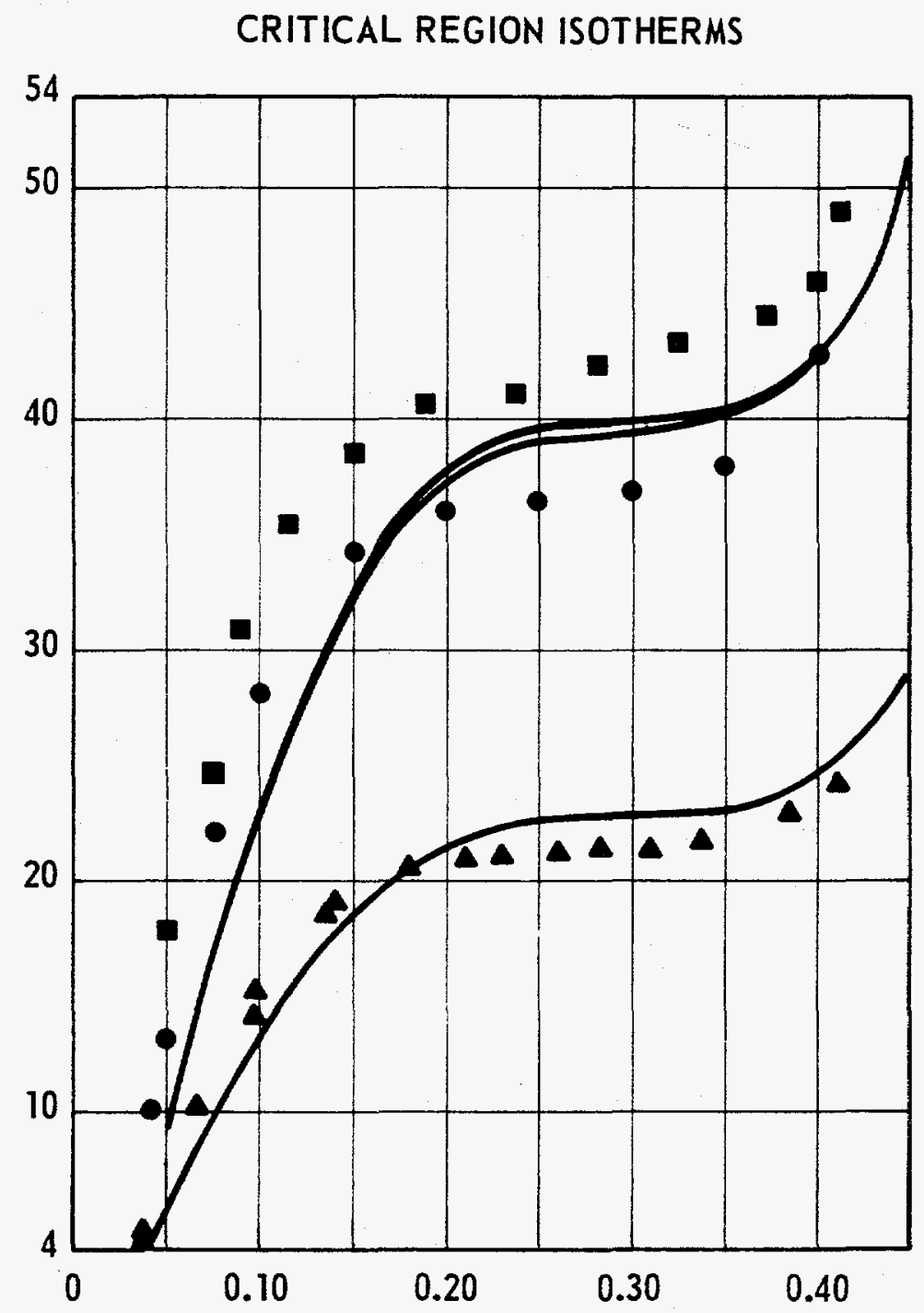




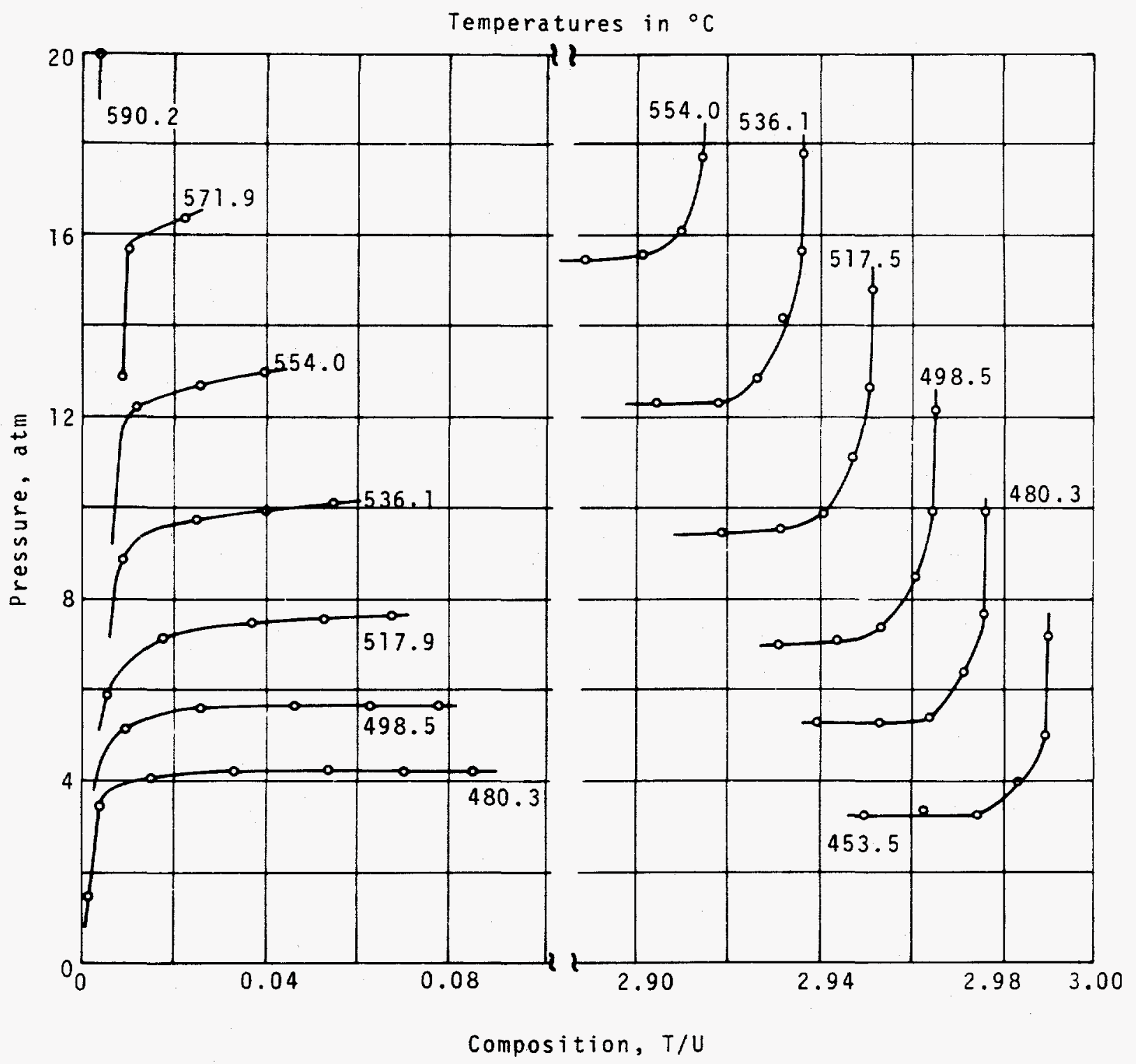




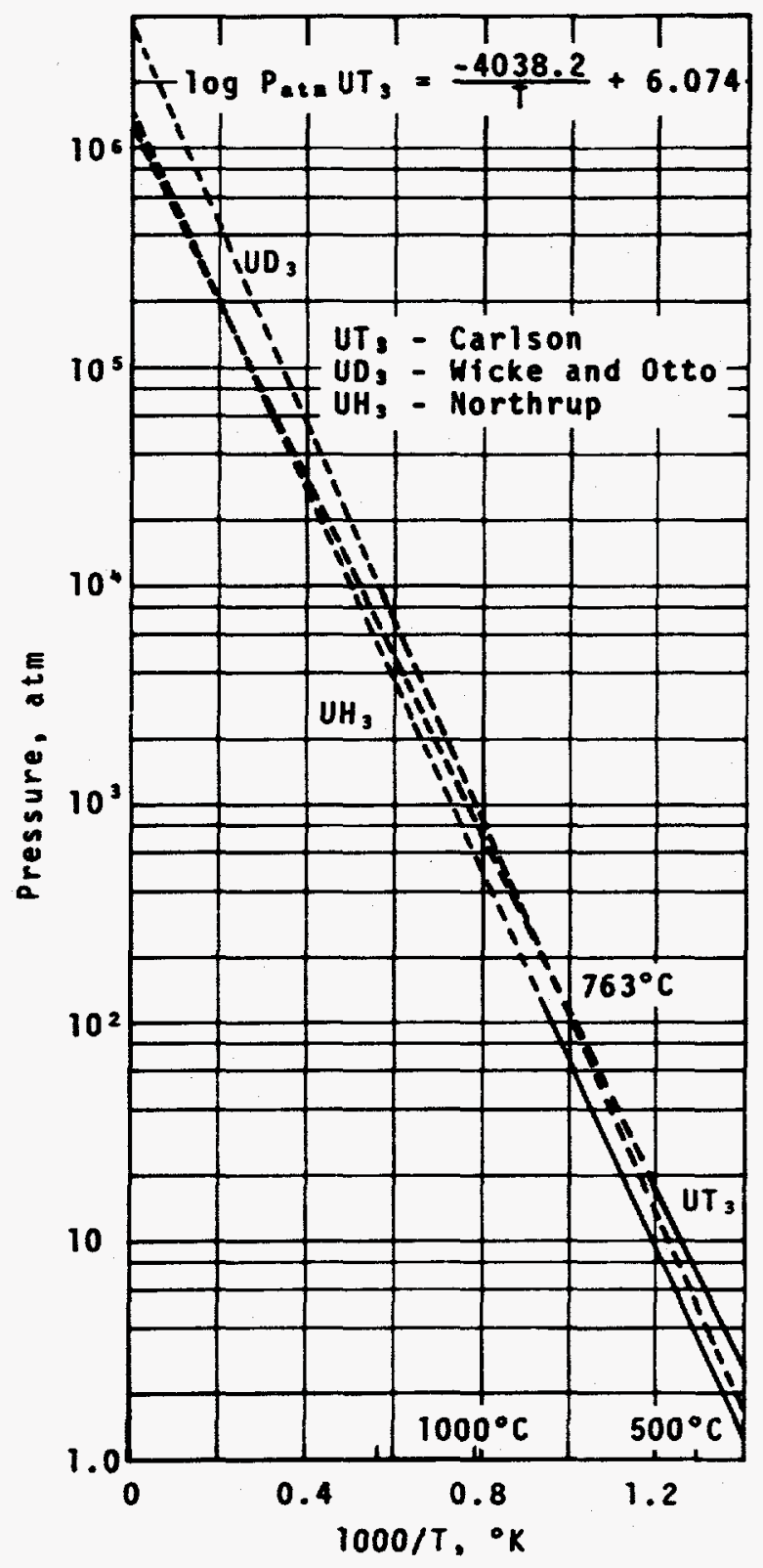


THERMODYNAMIC PROPERTIES OF URANIUM HYDRIDES

\begin{tabular}{|c|c|c|c|}
\hline & $\begin{array}{c}\Delta \mathrm{H}_{\mathrm{s}} \\
(\mathrm{kcal} / \mathrm{mole})\end{array}$ & $\begin{array}{c}\Delta S_{s} \\
\left(\mathrm{cal} /{ }^{\circ} \mathrm{K} / \mathrm{mole}\right)\end{array}$ & $\begin{array}{c}\Delta G_{s} \\
(\mathrm{kcal} / \mathrm{mole})\end{array}$ \\
\hline $\mathrm{UH}_{3}$ & -30.5 & -43.4 & -17.65 \\
\hline$U D_{3}$ & -30.8 & -44.8 & -17.5 \\
\hline$U D_{2} .66$ & -28.4 & -42.1 & -15.9 \\
\hline$U T_{2} .90$ & -27.7 & -41.7 & -15.3 \\
\hline
\end{tabular}


R. C. Bowman, Jr., Lattice Energy Calculations for the Alkali Hydrides, MLM-1764 (December 21, 1970), 21 pp.

R. C. Bowman, Jr., "Cohesive Energies of the Alkali Hydrides and Deuterides," J. Phys. Chem., 75, 1251-5 (1971).

R. C. Bowman, Jr., "Enthalpy of Solution of Divalent Impurities in NaF"l," Bull. Am. Phys. Soc., 16, 377 (1971).

R. C. Bowman, Jr., "Solubility of Divalent Impurities in the Alkali Halides," Phys. Rev. Letters, 26, 1239-41 (1971).

R. C. Bowman, Jr., "Calculations of Palladium Hydride Dissociation Pressure," Hydride Symposium Proceedings, Sandia Laboratories, Livermore, CA, April 15, 1971, SCL-M-710271 (June 1971), pp. 94-103 (SRD).

R. C. Bowman, Jr., Calculations of Equilibrium Constants for Lithium Hydride-Deuterium Exchange Reactions (U), MLM-CF-71-9-123. (Sept. 24, 1971), 19 pp. (SRD).

R. C. Bowman, Jr., and D. R. Locker, "EPR Investigation of UV Irradiated LiH," Bull. Am. Phys. Soc., 17, 308-9 (1972).

R. C. Bowman, Jr., and D. R. Locker, "EPR of Ultraviolet Irradiated Lithium Hydride Crystals," Solid State Comm., 11, 1489-1493 (1972).

R. C. Bowman, Jr., E. D. Seng1, and R. E. Sprague, Helium Release Measurements (U), MLM-CF-72-10-260 (Nov. 8, 1972), 17 pp. (SRD).

R. C. Bowman, Jr., "Thermal Expansion Coefficients of Lithium Hydride," J. Phys. Chem. Solids, 34:10, 1754-1756 (1973).

R. C. Bowman, Jr., "Theoretical Solution Enthalpies of Divalent Impurities in the Alkali Halides," J. Chem. Phys., 59:5, 2215-2223 (1973). 
G. C. Abe11, "Application of Diffusion Model for Recombination of Isolated Pairs in Condensed Media," J. Chem. Phys., $\underline{56}, 4079$ (1972).

G. C. Abe11, "Laplace Transform Method in the Theory of IonNeutralization," J. Chem. Phys., 56, 5422 (1972).

Mound Laboratory Chemistry and Physics Progress Report: April-June 1969, MLM-1606 (November 17, 1969), pp. 8-16.

R. S. Carlson, B. F. Hammond, H. R. Ratcliffe, MLM-CF-687-307 (SRD).

R. S. Carlson, "Preparation and Characterization of HighPurity Lithium Hydride Single Crystals," MLM-CF-70-9-63 (SRD).

R. S. Carlson, "Pressure-Composition-Temperature Relations of the Palladium-Hydrogen System," (U) MLM-CF-71-3-240 (SRD).

R. S. Car1son, "Pressure-Composition-Temperature Relations of the Palladium-25\% Silver-Hydrogen System," (U), MLM-CF-716-349 (SRD).

R. S. Carlson, "Pressure-Composition-Temperature Diagrams of the Palladium-Hydrogen System," (U), MLM-CF-72-1-242 (SRD).

R. S. Carlson, "The Vanadium-Hydrogen System," (U), MLM-CF-733-265 (SRD).

C. M. Love, L. J. Nielson and R. L. Yauger, "Reaction Kinetics and Isotope Exchange in the LiH- $\mathrm{D}_{2}$ System," (U), MLM-CF-70-6139 (SRD), MLM-CF-70-12-43 (SRD), and MLM-CF-71-3-240 (SRD).

C. M. Love, Synthesis by Exchange Techniques: Interim Report (U), MLM-CF-71-3-26 (March 19, 1971), 24 pp. (SRD).

C. M. Love and L. J. Nielson, "Physical Properties of Irradiated Li thium Hydride," (U), MLM-CF-70-9-63 (SRD); MLM-CF-70-12-43 (SRD) and MLM-CF-71-6-349 (SRD).

G. C. Abell, "The Theory of Hindered Rotation in Asymmetric Top Molecules," PhD Thesis, University of Notre Dame (1971). 
G. C. Abe11, "The Simple Exponential Distribution for Initial Electron-Positive Ion Separation Distances as Seen in the $\gamma$-Radiolysis of Alkanes," J. Chem. Phys., 58, 1079 (1973).

Papers to be published:

R. C. Bowman, Jr., and R. E. Sprague, "Helium Release Measurements," (U), Mound Laboratory Report (SRD).

R. C. Bowman, Jr., and A. Attalla, "Pulsed NMR Study of Heavily Irradiated Lithium Hydrides," (U), Mound Laboratory Report (SRD). 
Gas Dynamics and Cryogenic Separations 
CRYOGENICS

DISTILLATION
$\mathrm{H}_{2} / \mathrm{D}_{2} / \mathrm{T}_{2} \quad \mathrm{He}^{3} / \mathrm{He}^{4}$

\section{ISOTOPIC}

VAPOR PRESSURES
GAS DYNAMICS

MOLECULAR BEAM
THERMAL DIFFUSION

1 PhD PHYSICAL CHEMISTRY

2 PhD PHYSICS

2 B.S. PHYSICS

1 TECHNICIAN

THEORETICAL AND

PROGRAM LIBRARY

\section{ORDINARY DIFFUSION}


BLOCK FLOW DIAGRAM OF HYDROGEN ISOTOPE DISTILLATION SYSTEM

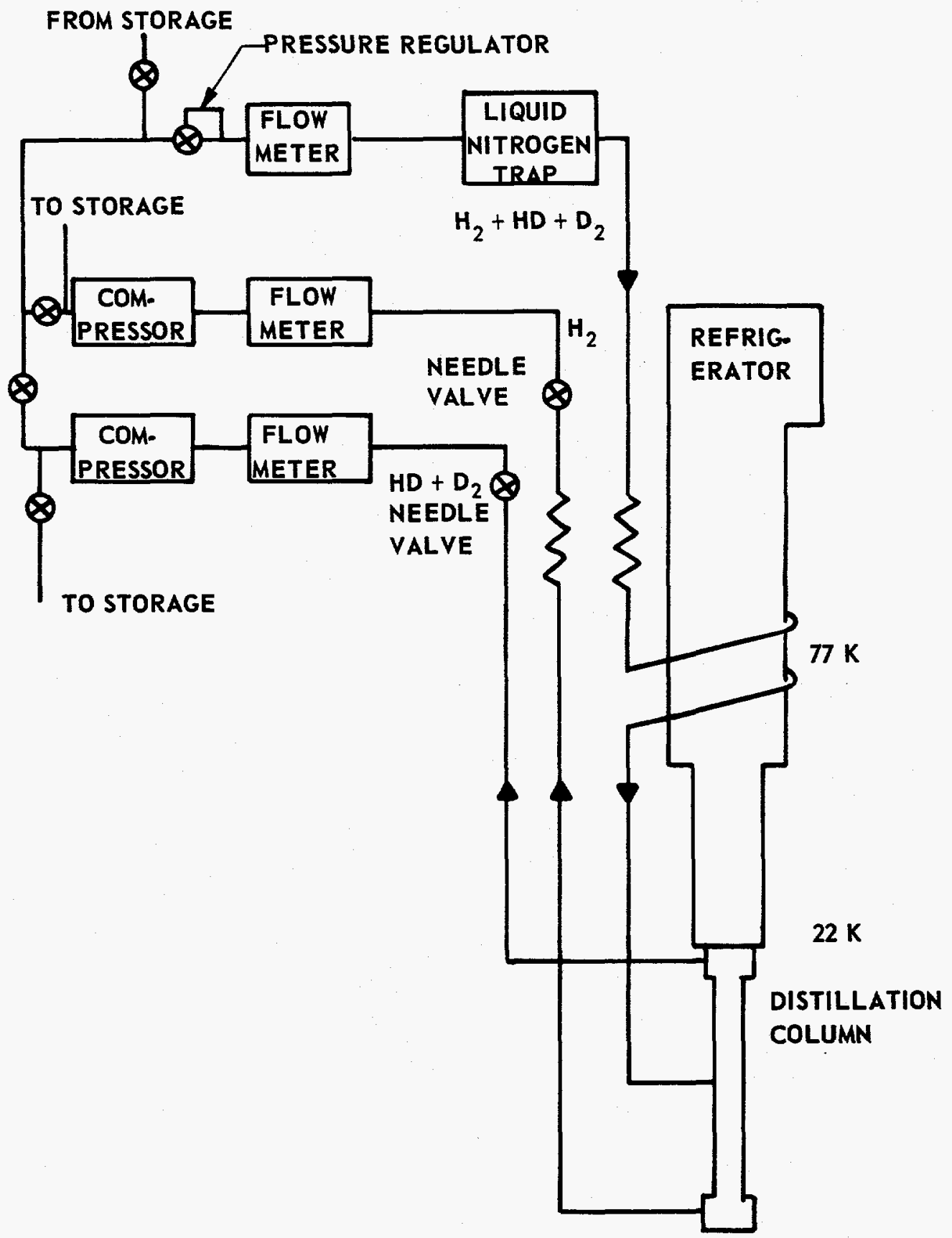


SCHEMATIC OF 2 COLUMN DISTILLATION APPARATUS

FOR THE SEPARATION OF PROTIUM FROM DEUTERIUM

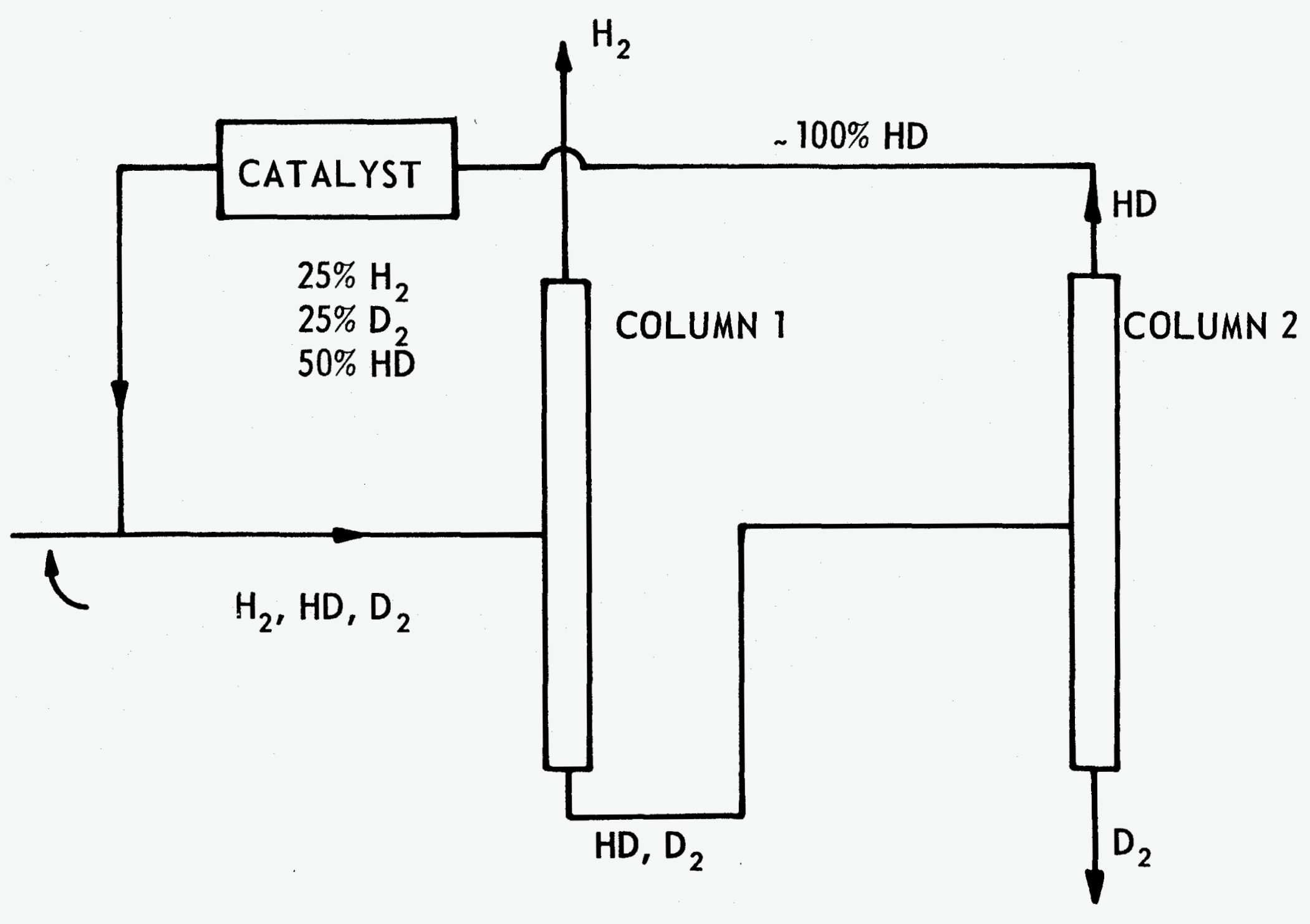




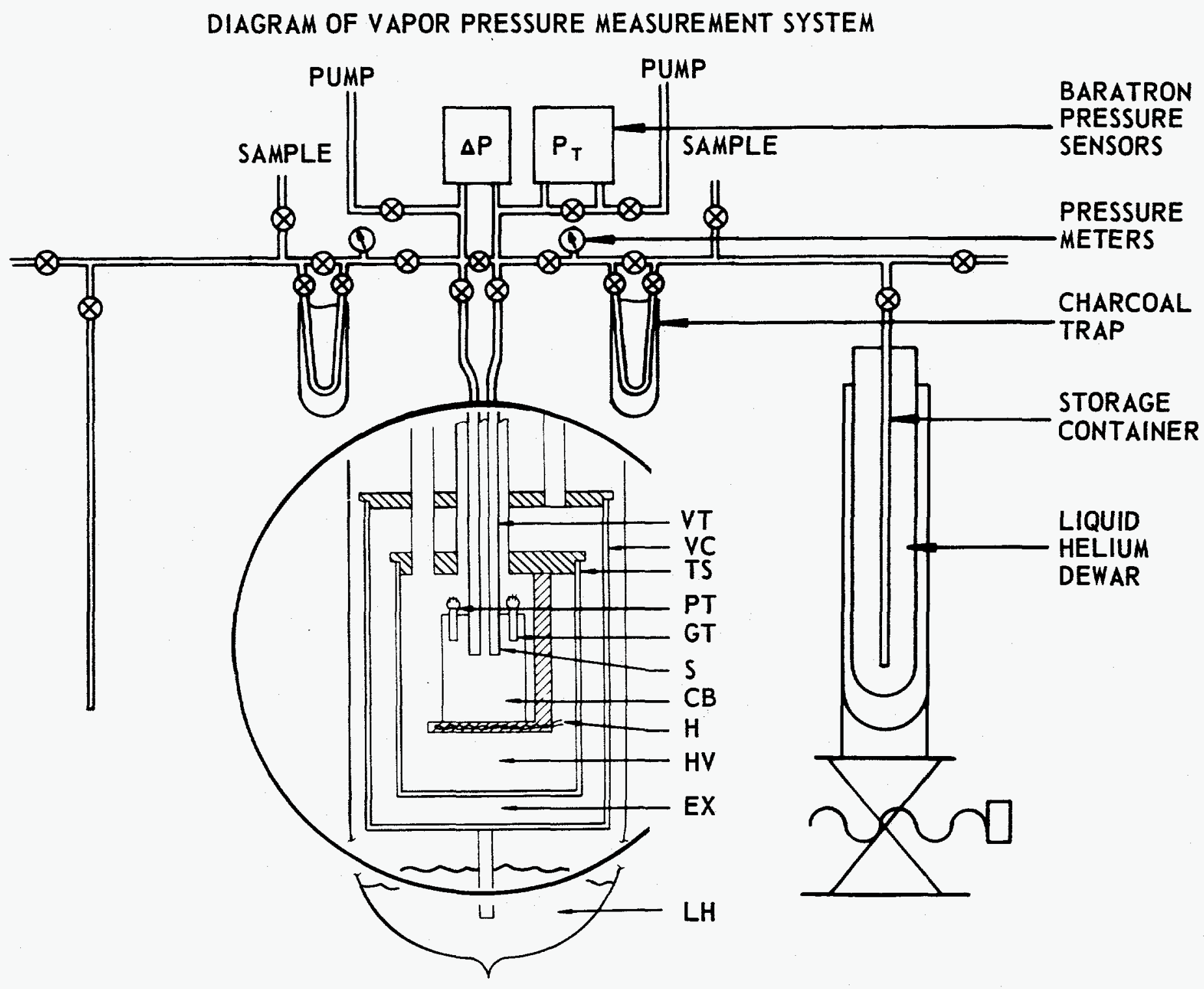




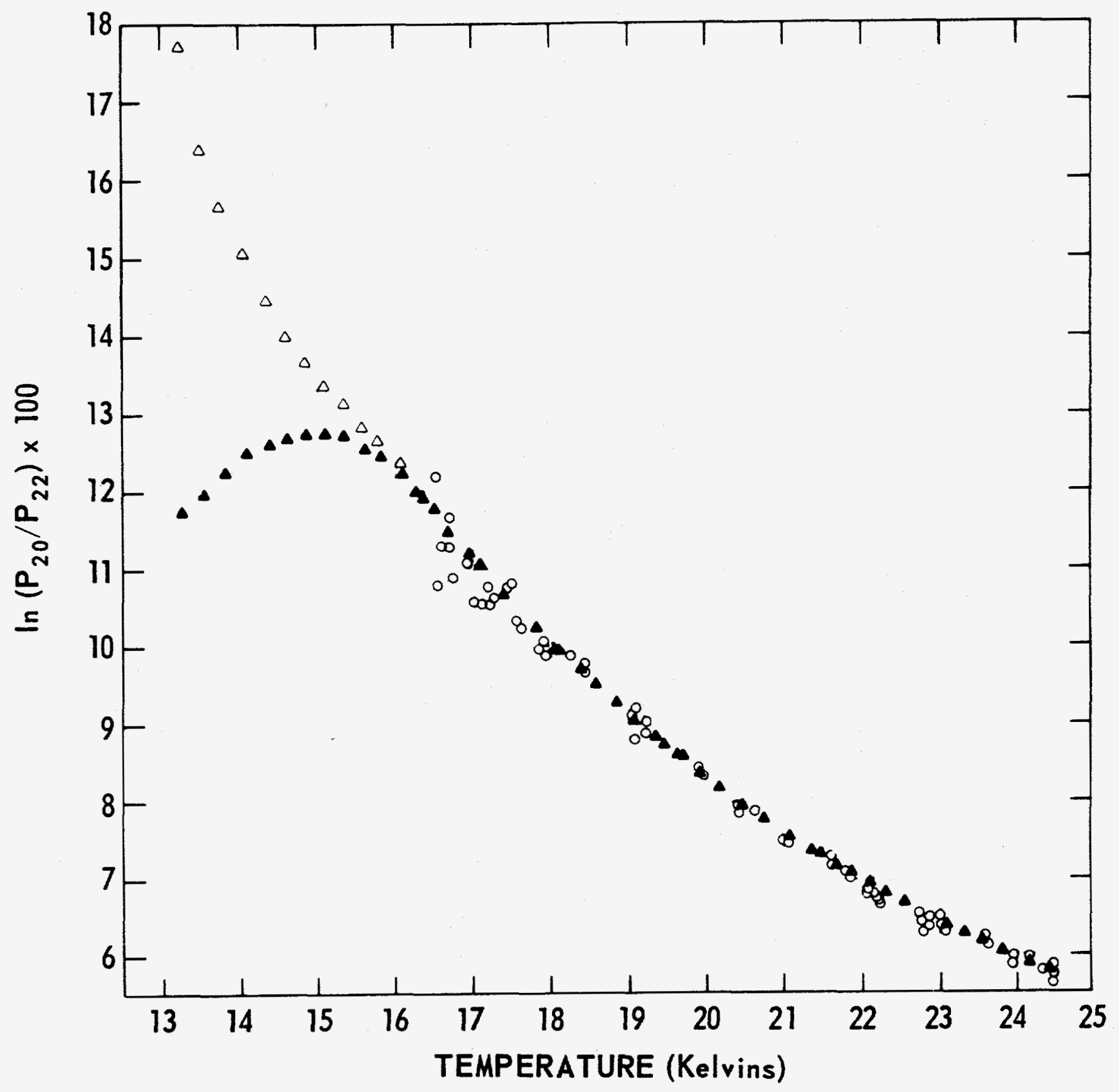


SIMPLE SINGLE COMPONENT ADSORPTION ISOTHERM APPARATUS

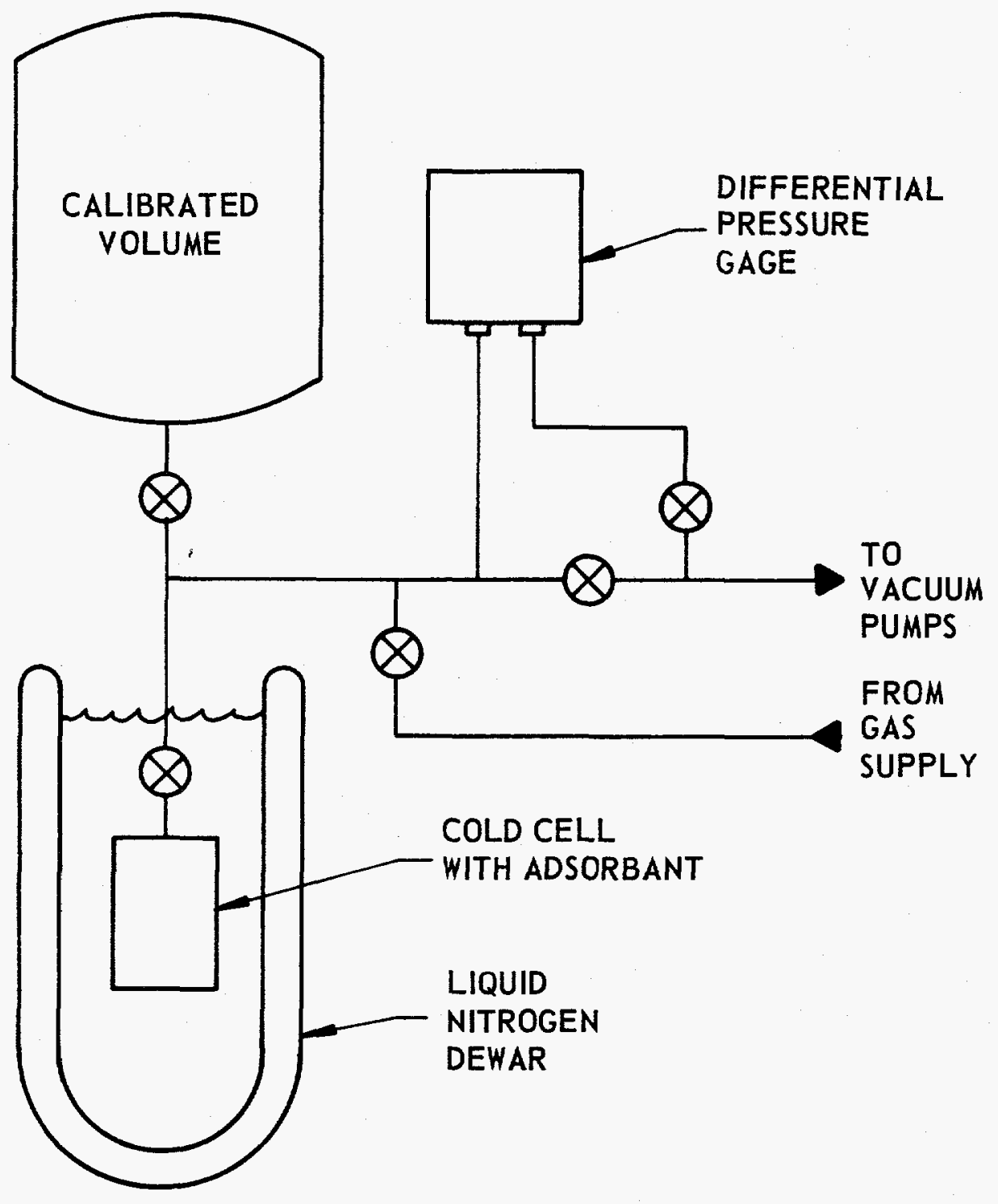




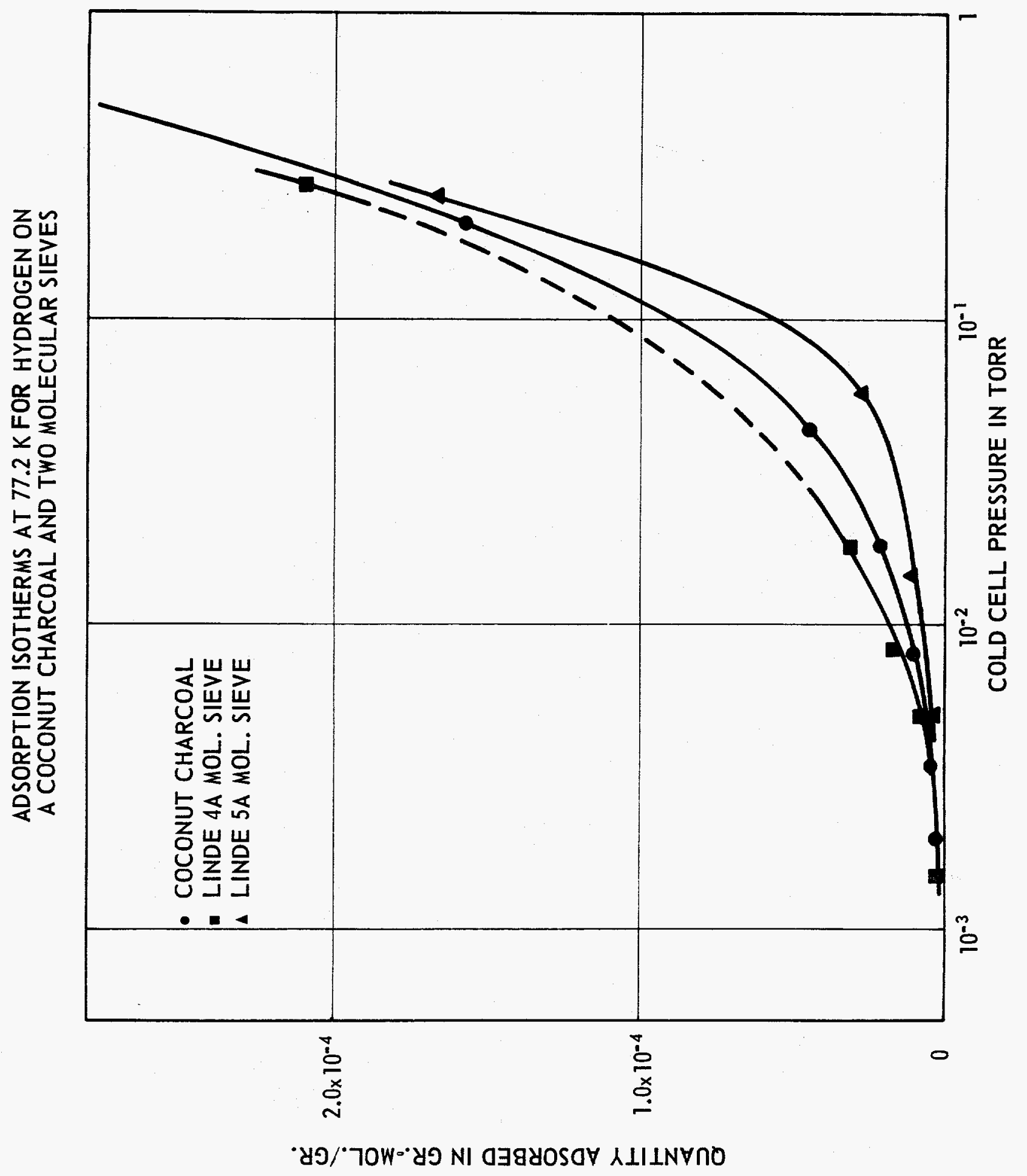




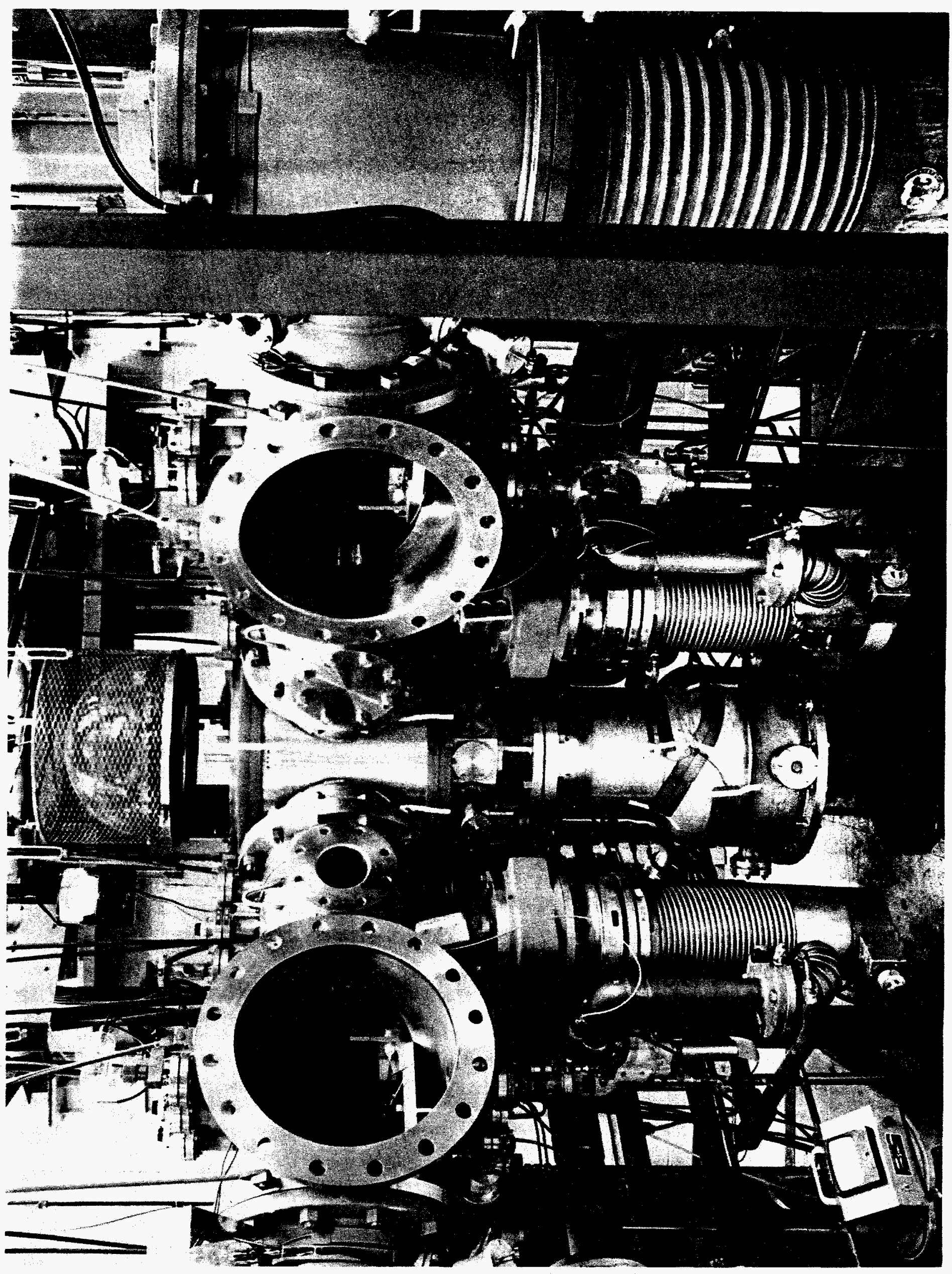



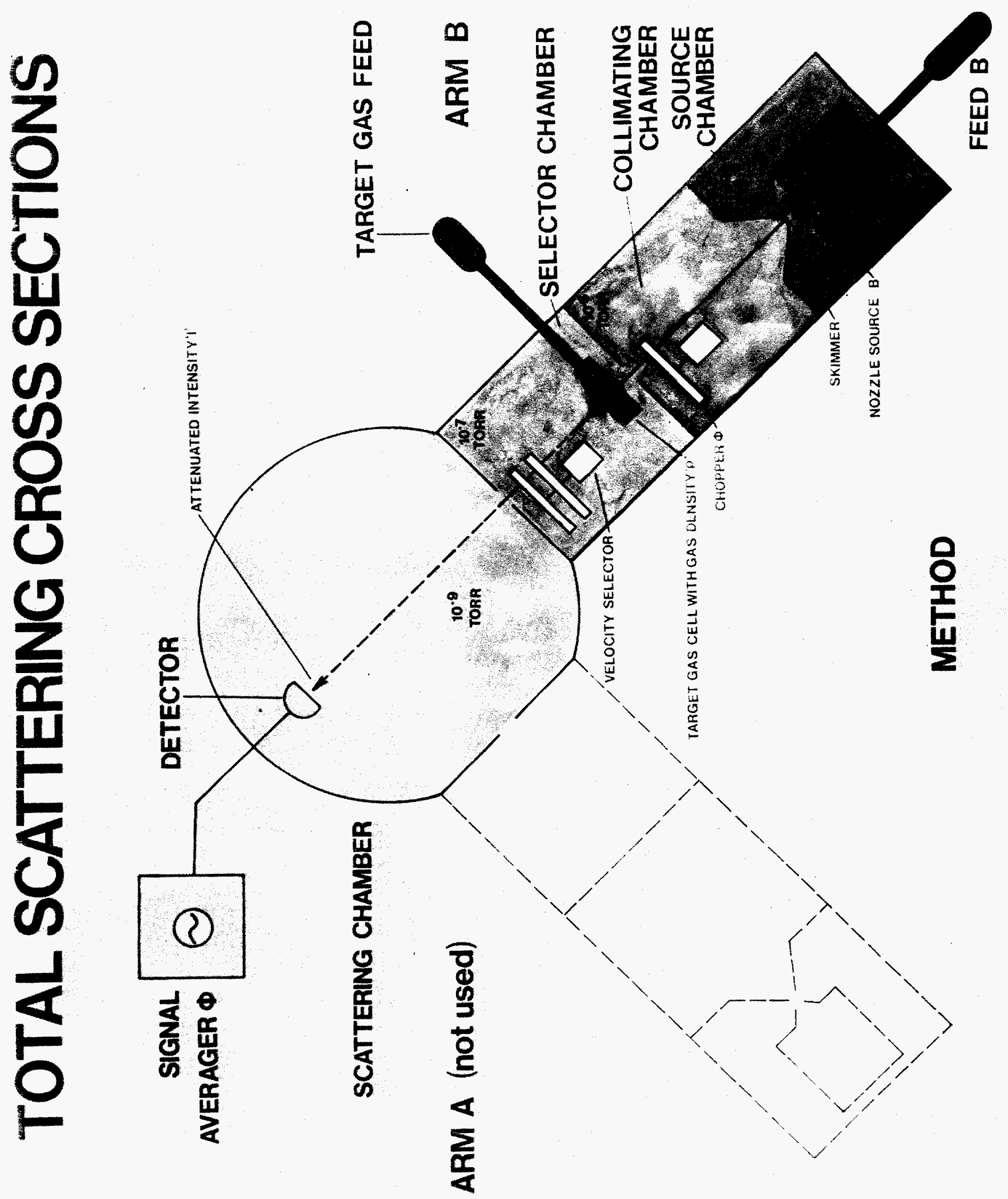


\section{DIFFERENTIAL SCATTERING CROSS SECTIONS}

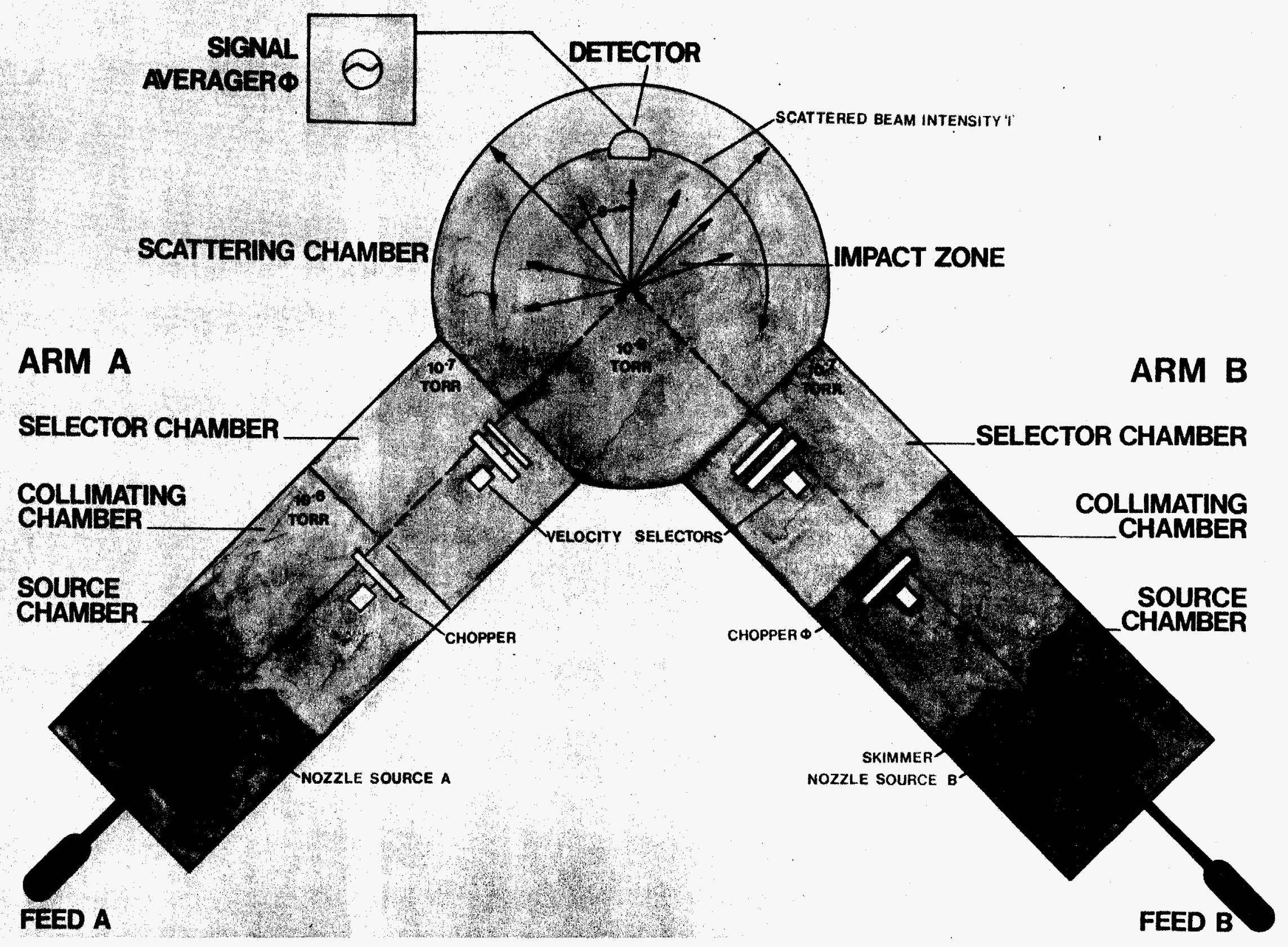




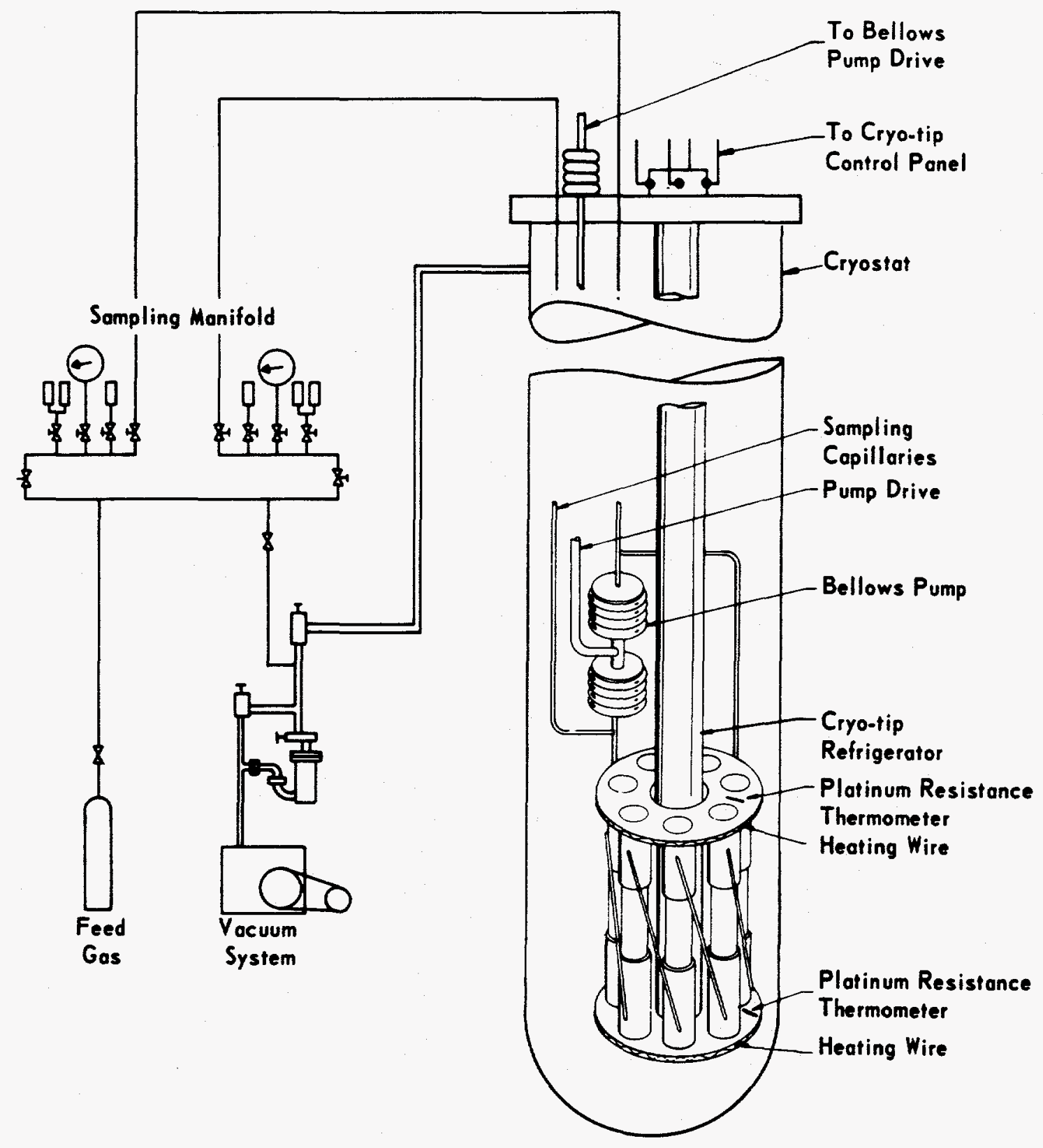




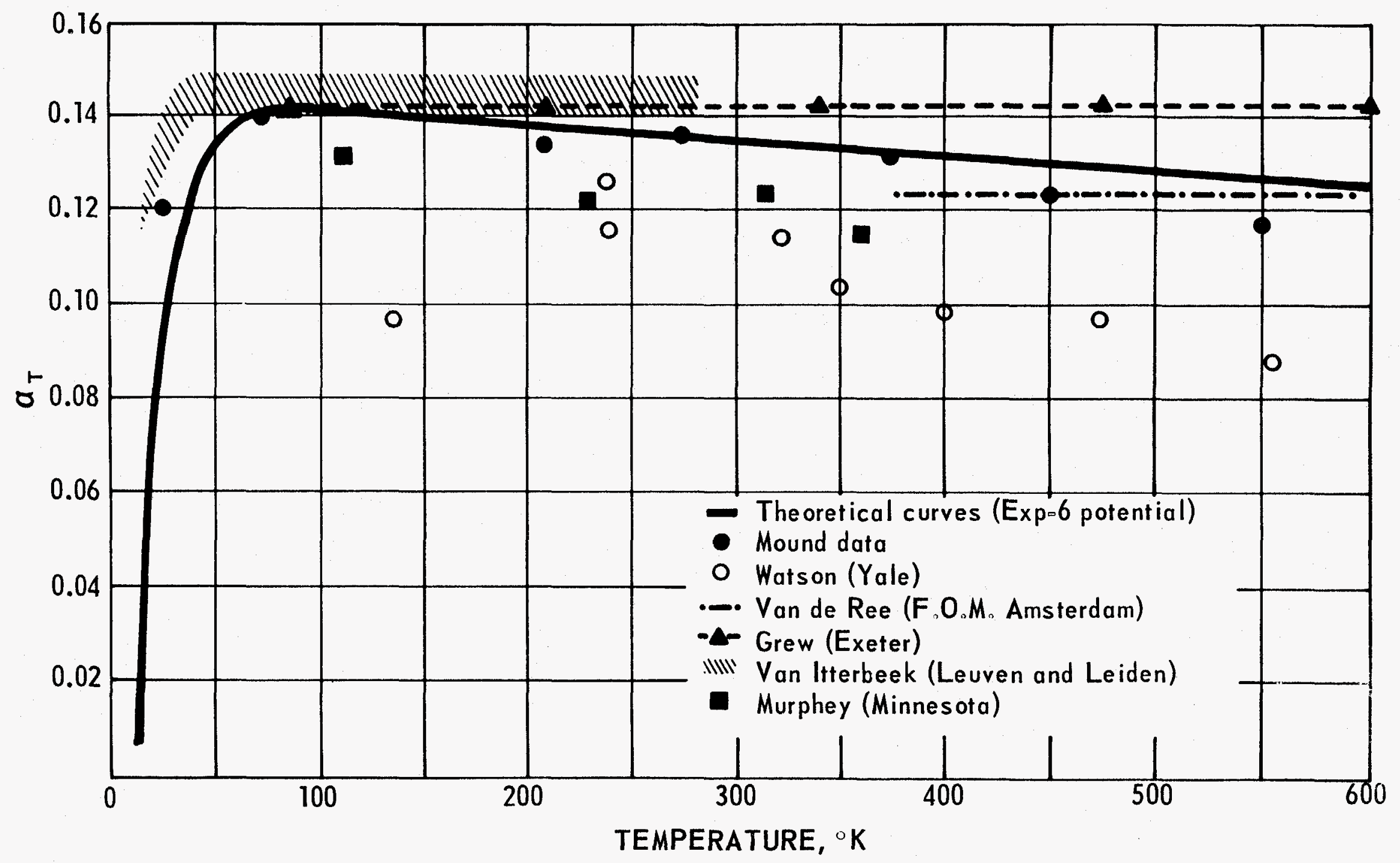




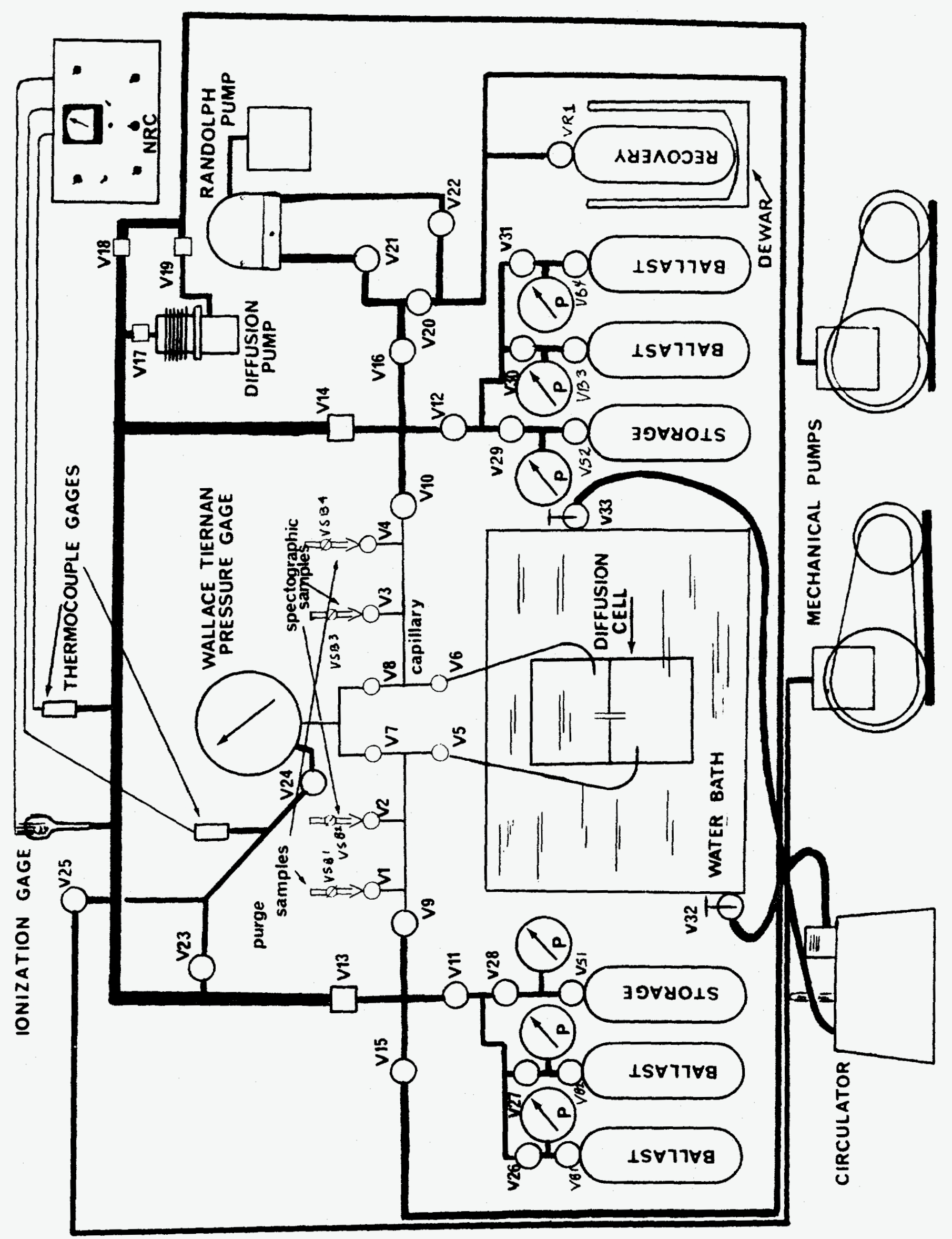


THERMAL DIFFUSION FACTORS FOR Kr

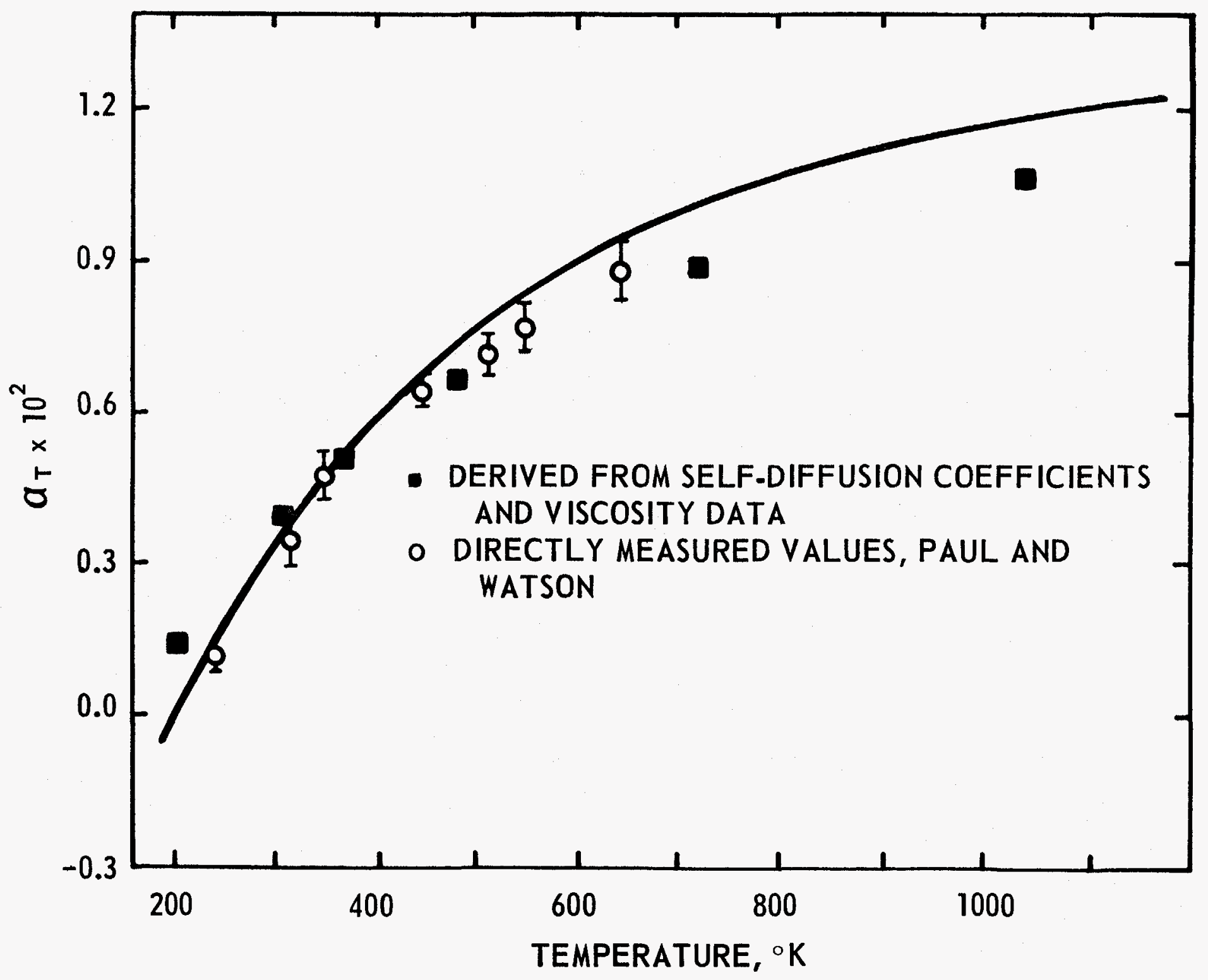



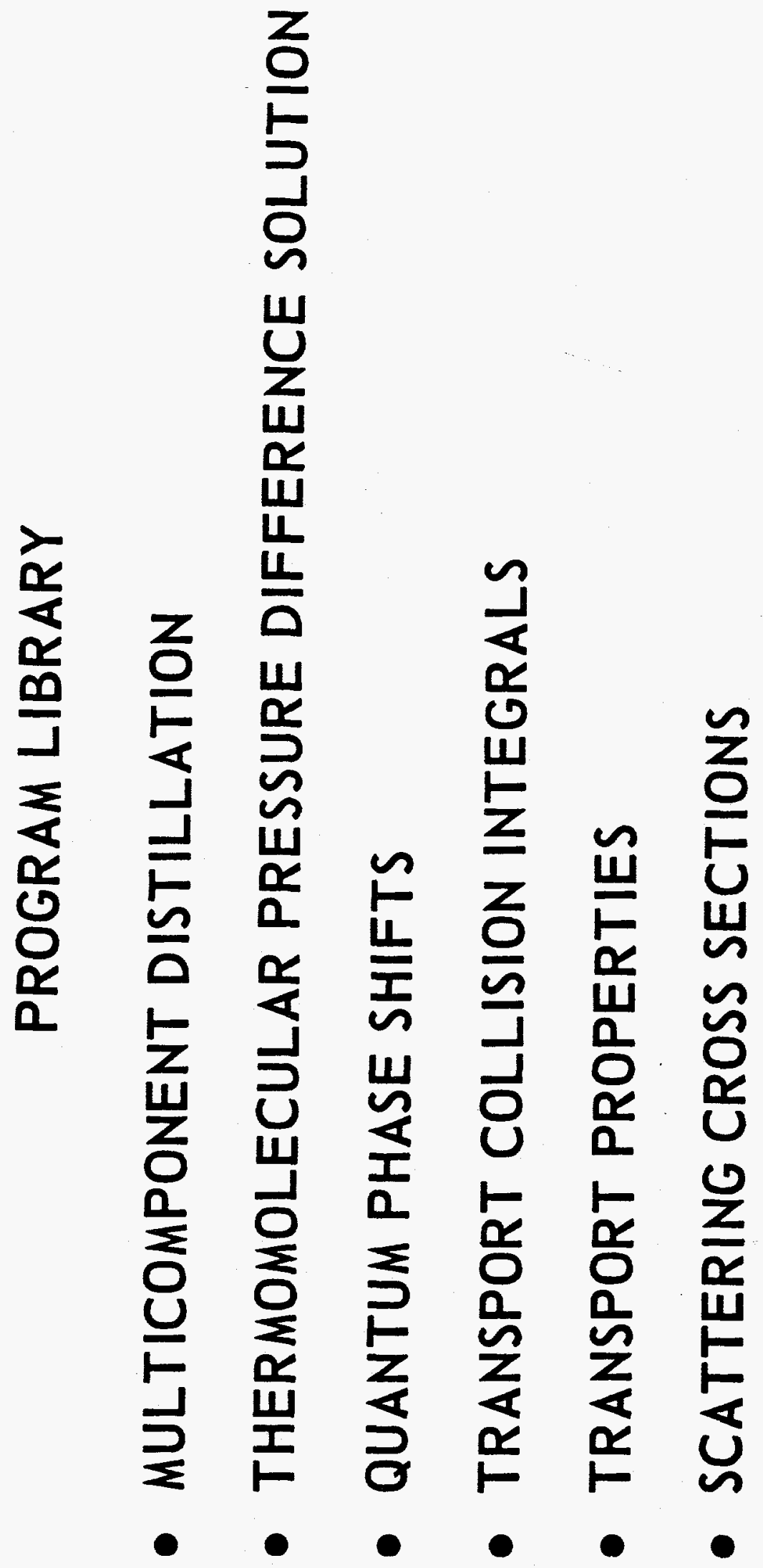


\section{GAS DYNAMICS AND CRYOGENIC SEPARATIONS}

\section{Selected Bibliography}

W. L. Taylor and S. Weissman, "Isotopic Thermal Diffusion Factor for Argon and Krypton, " J. Chem. Phys., 59:3, 1190-1195 (1973).

W. L. Taylor, "Thermal Diffusion Factor for the ${ }^{3} \mathrm{He}-4 \mathrm{He}$ System in the Quantum Region," J. Chem. Phys., 56, (1973).

W. L. Taylor, "Thermal Diffusion Factor of ${ }^{3} \mathrm{He}-{ }^{4} \mathrm{He}$ Mixtures: A Test of the Helium Interaction Potential," Proc. XIII Int. Conf. on Low Temperature Physics (August 1972).

W. L. Taylor, "Thermal Diffusion Factor and Quantum Collision Integrals for the $\mathrm{H}_{2}-{ }^{4} \mathrm{He}$ System: The Effect of Inelastic Collision", J. Chem. Phys., 57, 832 (1972).

W. L. Taylor and S. Weissman, "Thermal Diffusion Factors for the ${ }^{4} \mathrm{He}^{3} \mathrm{He}$ System," J. Chem. Phys., 55, 4000 (1971).

W. L. Taylor and G. T. McConville, "Cascade Measurements of Thermal Transpiration for $\mathrm{Ar}, \mathrm{Na}, \mathrm{CO}$, and the Helium Isotopes," J. Chem. Phys., 54, 5022 (1971).

W. L. Taylor and S. Weissman, "Composition Dependence of the Thermal Diffusion Factor for the $\mathrm{H}_{2}-\mathrm{He}$ System," J. Chem. Phys., 54, 3013 (1971).

W. L. Taylor and J. M. Keller, "Transport Properties of Helium Using Beck's Potential," J. Chem. Phys., 54, 647 (1971).

K. Berkling et al., Effective Collision Cross Sections in Scattering Experiments, MLM-1841 (TR) (August 20, 1971), 23 PP. [translated by W. L. Taylor from Zeitschrift für Physik, 966, 406-428 (1962)]. 
G. T. McConville, W. L. Taylor, and R. A. Watkins, "Analysis of the Determination of Rotational Relaxation Numbers from Thermal Transpiration," J. Chem. Phys., 53, 912 (1970).

W. L. Taylor and S. Weissman, "Thermal Diffusion Factors for the ${ }^{3} \mathrm{He}-{ }^{4} \mathrm{He}$ System, " Bull. Amer. Phys. Soc., 15:12, 1590 (1970).

W. L. Taylor and G. T. McConville, "Thermal Transpiration of Helium-3 and Helium-4 at Low Temperatures," Bul1. Amer. Phys. Soc., 15:11, 1366 (1970).

J. M. Keller and W. L. Taylor, "Evaluation of Transport Properties of Gases: The Bruch-McGee Potential for Helium," J. Chem. Phys., 51, 4829 (1969).

W. L. Taylor, S. Weissman, W. J. Haubach, and P. T. Pickett, "Thermal Diffusion Factors for the Neon-Xenon System," J. Chem. Phys., 50, 4886 (1969).

J. L. McKinney and W. L. Taylor, "Apparatus and Method for Separation of Helium Isotopes," U. S. Patent 3,421,344 (January 14, 1969).

S. Weber, Leiden Communications 223b, 246a, 246b, 246c and 246d, MLM-1549 (TR) (July 9, 1969), 102 pp. [translated by W. L. Taylor, D. M. Scott and S. M. Sydoriak from Leiden Communications].

W. L. Taylor and S. Weissman, "The Thermal Diffusion Factor of $\mathrm{H}_{2}-{ }^{4} \mathrm{He}$ Mixtures," Bul1. Amer. Phys. Soc., 14:12, 1188 (1969).

G. T. McConville, W. I. Taylor, and R. A. Watkins, "On the Determination of Rotational Relaxation Numbers from Thermal Transpiration Measurements," Bul1. Amer. Phys. Soc., 14:4, 527 (1969). 
R. A. Watkins, W. L. Taylor, and G. T. McConville, "Low Temperature Therma1 Transpiration and Molecular Rotationa1 Relaxation," Proceedings of the 11th Int. Conf. on Low Temperature Physics, St. Andrews, Scotland, Vol. I, P. 585-8, 1968 (issued in 1969).

H. J. Beier, Scattering from Helium Atomic Beams in Rare Gases, MLM-1553 (TR) (September 3, 1968), 22 pp. Ttranslated by W. L. Taylor from Zeitschrift für Physik, 196, 185-202 (1966)].

G. T. McConville, R. A. Watkins, and W. L. Taylor, "Deviations from the Weber-Schmidt Equation for Thermomolecular Pressure Difference of ${ }^{3} \mathrm{He}$ and ${ }^{4} \mathrm{He}, "$ Proc. 10th Int. Conf. Low Temp. Phys., Moscow, 1966 (Proizvodstrenno-Izdatel'skii Kombinat, VINITI, Moscow, USSR, 1967).

W. L. Taylor and S. Weissman, "Composition Dependence of the Thermal Diffusion Factor of the Xe-Ne System," Phys. Fluids, 10, 668 (1967).

R. A. Watkins, W. L. Taylor, and W. J. Haubach, "Erratum: Thermomolecular Pressure Difference Measurements for Precision Helium-3 and Helium-4 Vapor-Pressure Thermometry," J. Chem. Phys., 47, 3692 (1967).

R. A. Watkins, W. L. Taylor, and W. J. Haubach, "Thermomolecular Pressure Difference Measurements for Precision Helium-3 and Helium-4 Vapor Pressure Thermometry," J. Chem. Phys., 46:3, 1007 (1967).

G. T. McConville, R. A. Watkins and W. L. Taylor, "Corrections in ${ }^{3} \mathrm{He}$ Vapor Pressure Thermometry for Different Values of the Momentum Accommodation Coefficient," Ann. Acad. Sci. Fennicae: Ser. A201, 44, (1966).

G. T. McConville, R. A. Watkins, and W. L. Taylor, "Physical Content of the Weber-Schmidt Equation for Thermomolecular Pressure Difference," Bull. Am. Phys. Soc., Series 2, Vol. 11, p. 93 (1966). 
G. T. McConville, "The Effect of the Measuring Surface on Thermomolecular Pressure Corrections in Vapor Pressure Thermometry", Temp. Meas. Control Sci. Ind. 5th Symposium Vo1. I, $159(1973)$.

G. T. McConville, "Vapor Pressure Ratios of the Neon Isotopes", Proceedings of the XIII Conference on Low Temperature Physics (in press) (1973).

G. T. McConville, "Analys is of Vapor Pressure Ratio Data Using Wigner-Kirkwood Free Energy Expansion", MLM-2088 (January 31, 1974), $22 \mathrm{pp}$.

G. T. McConville, "Vapor Pressure Ratios Over the Solid Neon Isotopes (submitted to J. Low Temp. Phys., 1973).

G. D. Cody, J. J. Hanak, G. T. McConville, "Effect of Hydrogen and Deuterium on Superconducting Transition of Lanthanum," Am. Phys. Soc. Bul1 5, Ser II, 290 (1961).

G. D Cody, J. J. Hanak, G. T. McConville, "Resistance Anomaly in Beta-Tungsten Compounds," APS Bul1 6, Ser II, 146 (1961) - Also Technical Documentary Rpt. No. ASD-TDR-62-1111.

B. Serin and G. T. McConville, "Heat Capacity of Superconductors in Magnetic Field." 1963 Calorimetry Conference, Bartelsville, ok1a.

T. McConville and B. Serin, "Specific Heat of Type II Superconductors in a Magnetic Field," Conf. on Type II S. C., Western Reserve Univ., Aug. 1964 (unpublished).

G. T. McConville, "Vapor Pressure Ratio of ${ }^{2}{ }^{\mathrm{Ne}}$ and ${ }^{2 a} \mathrm{Ne}, "$ Bul1. Am. Phys. Soc. 17, Ser. II, 351 (1972).

G. T. McConville, "Vapor Pressure of Solid $21 \mathrm{Ne}$ " Bull. Am. Phys. Soc. 18, Ser. II, 673 (1973). 
W. R. Wilkes and D. E. Mapother, "Specific Heat of Sn and Sn-In Alloys," Bull. Phys. Soc., 10, 346 (1965).

W. R. Wilkes and D. E. Mapother, "Normal Electronic and Lattice Specific Heats of Dilute Tin-Indium Alloys," Proceedings of the 1966 Low Temperature Calorimetry Conference (Annales Academiae Scientiarum Fennicae, A VI, No. 210, 1966).

W. F. Gauster, K. R. Efferson, J. B. Hendricks, H. A. U11maier, W. R. Wilkes, "On the Stability of Superconducting Magnets," Cryogenics 8 , 13 (1968).

W. R. Wilkes, "A Continuous Distillation Apparatus for the Separation of ${ }^{3} \mathrm{He}$ from ${ }^{4} \mathrm{He}, "$ Advances in Cryogenic Engineering, 16, Plenum Press, New York, in press.

W. R. Wilkes, "A ${ }^{3} \mathrm{He}$ Refrigerator Not Requiring a Pumped ${ }^{4} \mathrm{He}$ Bath," Proceedings of the Commission I Meeting of the International Institute of Refrigeration, Tokyo, 1970 (Supplement 1970-2 to the Bulletin of the Internationa1 Institute of Refrigeration).

W. R. Wilkes, "A $200 \mathrm{~mW}$ Recirculating Helium-3 Refrigerator," Cryogenics 12, 180 (1972).

W. R. Wilkes, "Distillation of Helium Isotopes," Proceedings of ICEC-4, Eindhoven, 1972, IPC Science and Technology Press (1972) p. 119.

W. R. Wilkes, "3 $\mathrm{He}^{-4} \mathrm{He}$ Distillation Apparatus," MLM-2005 (March 21, 1973), 15 pp.

Contribution Via Personal Communication to "A Proposal for a $14 \mathrm{MeV}$ Intense Neutron Source at Los Alamos, New Mexico," LA -5191-P (1973). 
G. D. Cody, J. J. Hanak, G. T. McConville, F. D. Rosi, "Superconducting Properties of the (Nb, Ta, V) ${ }_{3} \mathrm{Sn}$ System" Proc. of VII Int. Conf. on Low Temp. Phys., North Holland, 1961, p. 382 .

T. McConville, B. Serin, "Thermal and Magnetic Properties of Second Kind Superconductors III. Specific Heat of Nb in a Magnetic Field," Rev. Mod. Phys., 36, 112 (1964).

T. McConville, B. Serin, "Specific Heat of Type II Superconductors in a Magnetic Field," Phys. Rev. Lett. 13, 365 (1964).

T. McConville, B. Serin, "Ginsberg-Landau Parameters of Type II Superconductors," Phys. Rev., 140, A1169 (1965).

G. T. McConville, W. L. Taylor, R. A. Watkins, "Corrections in ${ }^{3} \mathrm{He}$ Vapor Pressure Thermometry for Different Values of Momentum Accommodation Coefficient", Ann. Acad. Sci. Finnic A. VI, No. 210,44 (1966).

G. T. McConville, "Thermomolecular Pressure Corrections in Vapor Pressure Thermometry: The Effect of the Tube Surface Cryogenics $\underline{9}, 122$ (1969).

G. T. McConville, Derivation of Modified Weber-Schmidt Equa for Thermal Transpiration, MLM-1627 (June 1, 1969), 18 pp. 
W. L。 Taylor and W. J. Haubach, "Thermal Diffusion Factors for the Neon-Xenon System," Buil. Am. Phys. Soc., Sec. 11, 766 (1966).

S. Weissman and W. L. Taylor, "Thermal Diffusion Factor of the System Ne-Xe as a Function of Temperature and Composition," Bull. Am. Phys. Soc. Series 2, Vol. 11, (1966).

J. M. Keller and W. L. Taylor, "Collision Integrals for Theoretical Helium Intermolecular Potentials," Bull. Am. Phys. Soc. Series 2, Vo1. 10, p. 1183, MLM-1329J (1965).

W. L. Taylor and R. A. Watkins, "Thermomolecular Pressure Difference Measurements for Helium-3 and Helium-4," Bul1. Am. Phys. Soc. 10, 735 (1965).

W. J. Haubach and W. L. Taylor, "Helium-3 and Low Temperature Thermometry," Research/Development, p. 19 (September 1964).

W. L. Taylor, "The Theory and Operation of a Device for the Measurement of the Coefficient of Thermal Diffusion in Gases," in Symposium on Research at Mound Laboratory June 6-7, 1963, MLM-1163.

B. L. van der Waerden, Theory of the Trennschauke1, MLM-1181 (October 14, 1963), 62 pp. [translated by W. L. Taylor from Zeitschrift fur Naturforeluing, 12a, 583-598 (1957)].

W. L. Taylor, "Intermolecular Potentials for Ar, CO, and Cyclohexane," Ph.D. Thesis (1962).

Papers to be Submitted

W. L. Taylor, "A Test of Intermolecular Potentials for the Noble Gases by Comparison with Experimental Thermal Diffusion Factors," Proc. of the Noble Gases Symposium, U.S.E.P.A. (September 1973).

W. L. Taylor and Stanley Weissman, "Experimental Thermal Diffusion Factors for $20 \mathrm{Ne}-{ }^{2} \mathrm{Ne}$ and Their Applications as a Test of the Neon Interatomic Potential," (accepted by J. Chem. Phys.). 
Doc. No. MLM-72-6-109, "Method for Encapsulating Fue1 for Controlled Thermonuclear Reactors," (S-RD).

In Preparation

W. L. Taylor and R. A. Aziz, "On the Determination of the Intermolecular Potential Energy Function of Neon from Spectroscopic, Equilibrium and Transport Data" (comment to be submitted to Molecular Physics).

W. L. Taylor, "Therma1 Diffusion Factors for Xenon" (to be submitted to J. Chem. Phys.). 
SPECIALIZED MECHANICAL TESTING EQUIPMENT

- HIGH-TEMPERATURE, HIGH-VACUUM CREEP TESTERS

- HIGH-TEMPERATURE, HIGH-VACUUM FATIGUE TESTER

- HIGH-TEMPERATURE, HIGH-VACUUM, LARGE $(6 \times 8$ in.) ANNEALING FURNACE

- MTS TEST SYSTEM LOCATED IN TRITIUM-CONTROLLED GLOVE BOX LINE

- HIGH-TEMPERATURE IMPACT FACILITY 
RESEARCH ANALYTICAL EQUIPMENT

- TRANSMISSION ELECTRON MICROSCOPES

- SCANNING ELECTRON MICROSCOPES

- X-RAY EQUIPMENT

- ELECTRON MICROPROBE 
TRITIUM CONCENTRATION (ppm by wgt.)
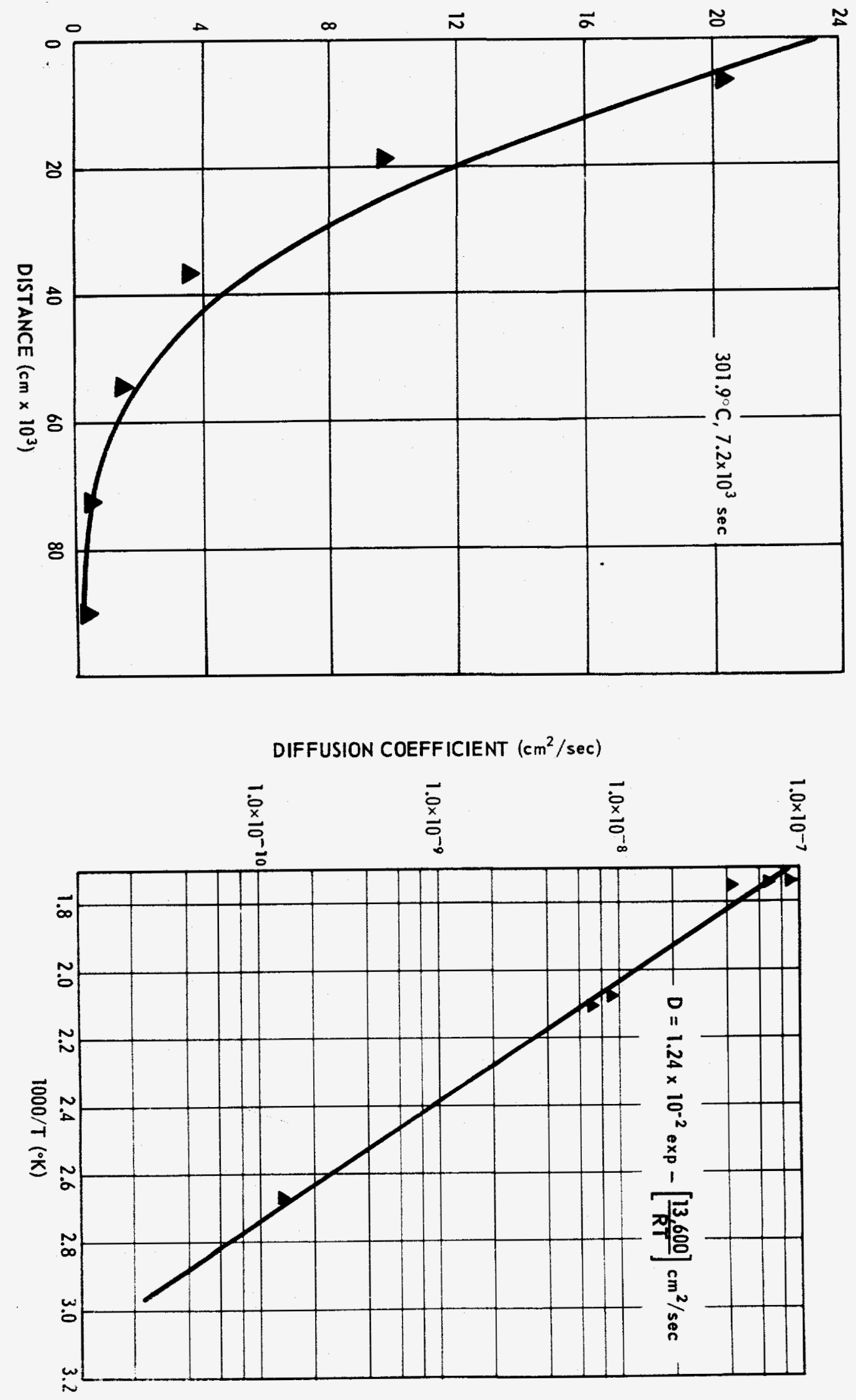


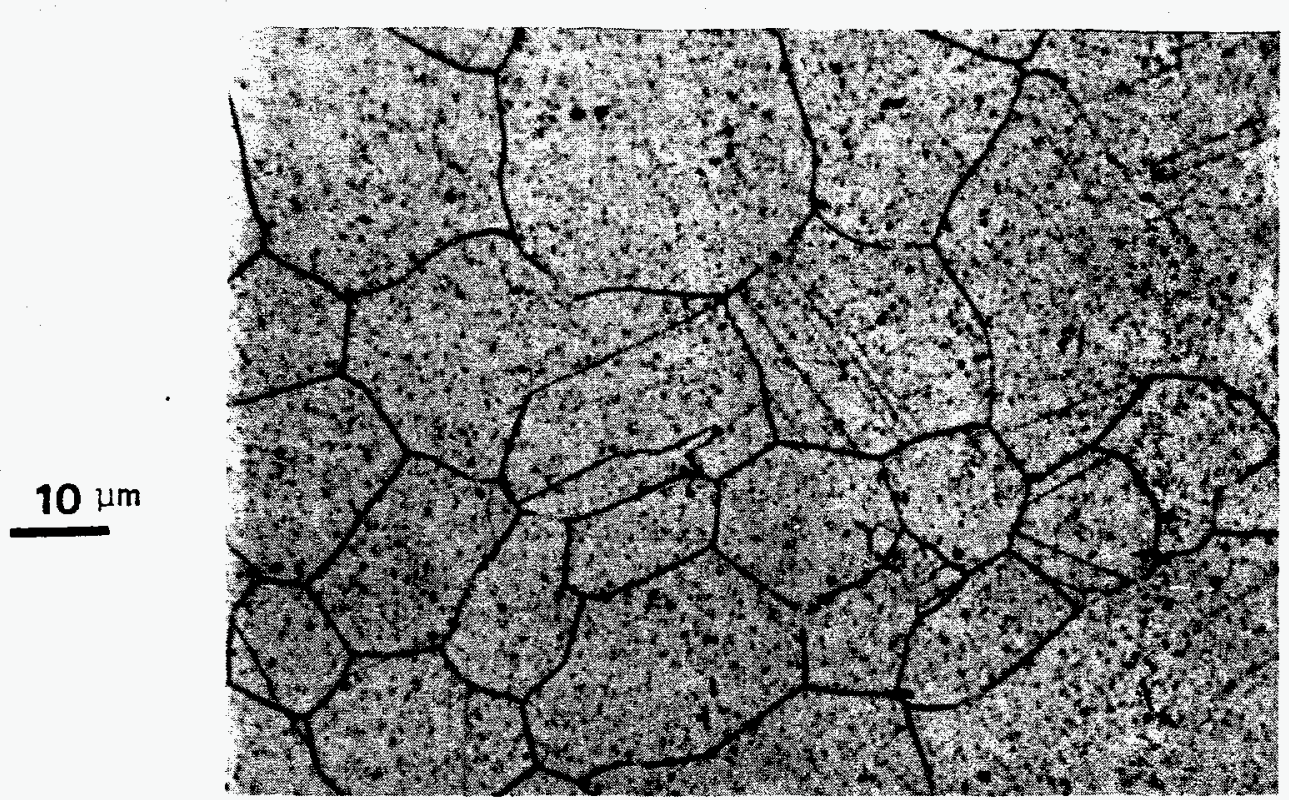

A.

\section{ANNEALED}

STAINLES S STEEL

$1000 \times$

B.

COLD-WORKED

STAINLESS STEEL

$1000 \times$

C.

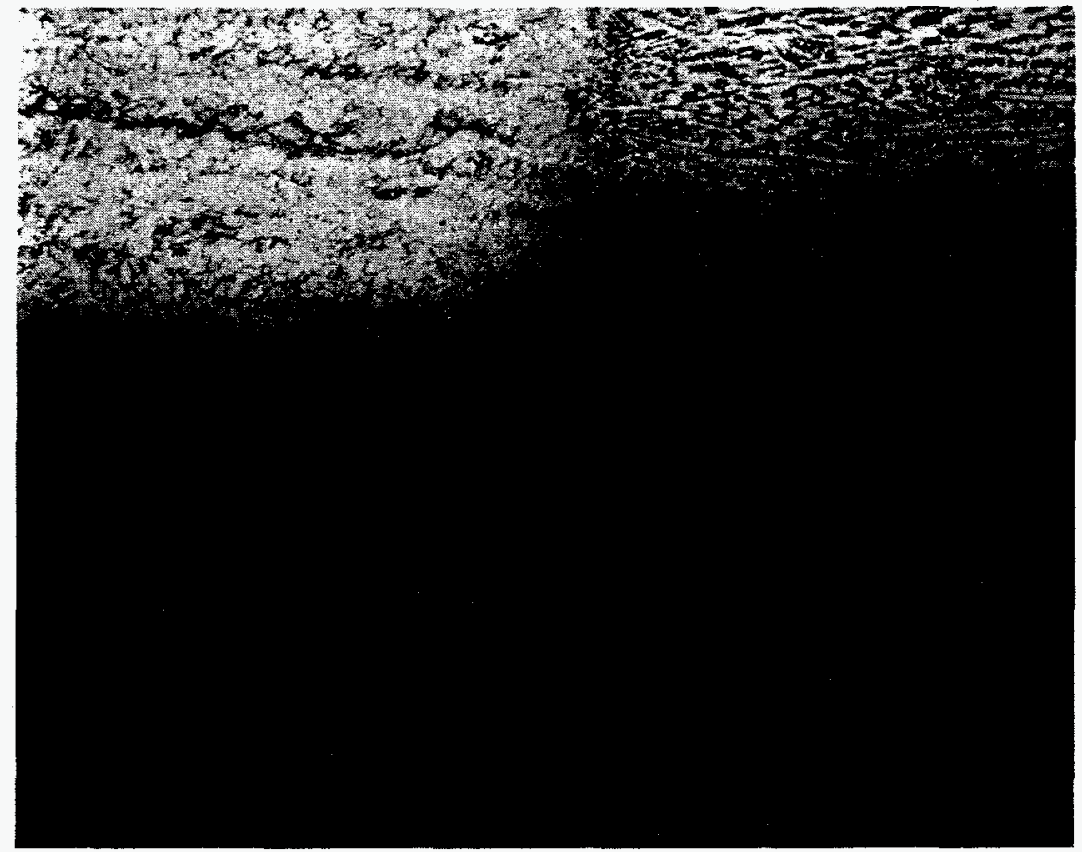

ENHANCED PENETRATION

IN WELD METAL

$100 x$ 


\section{PERMEABILITY CONSTANTS OF NONRADIOACTIVE HYDROGEN ISOTOPES AT $25^{\circ} \mathrm{C}$}

\begin{tabular}{|c|c|c|c|c|}
\hline MATERIAL & $\begin{array}{l}\text { SPECIMEN } \\
\text { THICKNESS } \\
(\mathrm{cm})\end{array}$ & ISOTOPE & $\begin{array}{c}\text { MEASURED } \\
\text { PERMEABILITY } \\
\text { CONSTANT Q } \\
\left(\mathrm{cm}^{2} / \mathrm{sec} \cdot \mathrm{atm}\right) \\
\end{array}$ & $\begin{array}{l}\text { LITERATURE } \\
\text { VALUE } \\
\left(\mathrm{cm}^{2} / \mathrm{sec} \cdot \mathrm{atm}\right)\end{array}$ \\
\hline Latex & 0.018 & $\mathrm{H}_{2}$ & $3.5 \times 10^{-7}$ & $3.9 \times 10^{-7}$ \\
\hline Latex & 0.018 & $D_{2}$ & $3.0 \times 10^{-7}$ & \\
\hline Mylar & 0.005 & $\mathrm{H}_{2}$ & $4.5 \times 10^{-9}$ & $4.4 \times 10^{-9}$ \\
\hline Mylar & 0.005 & $D_{2}$ & $4.1 \times 10^{-9}$ & \\
\hline Teflon & 0.007 & $\mathrm{H}_{2}$ & $6.1 \times 10^{-8}$ & \\
\hline Teflon & 0.007 & $D_{2}$ & $5.7 \times 10^{-8}$ & \\
\hline Saran & 0.001 & $\mathrm{H}_{2}$ & $3.6 \times 10^{-8}$ & $3.1 \times 10^{-7}$ \\
\hline Saran & 0.001 & $D_{2}$ & $2.3 \times 10^{-8}$ & \\
\hline
\end{tabular}


HELIUM DIFFUSION AND PERMEABILITY STUDIES

- $\mathrm{PuO}_{2}$ PLASMA-FIRED MICROSPHERES

- $\mathrm{PuO}_{2}$ SOL-GEL MICROSPHERES

- Pu metal

- $\mathrm{PuO}_{2}$-Mo CERMET

- REFRACTORY METALS

TRITIUM DIFFUSION IN STAINLESS STEELS 
MECHANICAL TESTING OF DOPED METALS AND ALLOYS

- TENSILE TESTS

- HOT IMPACT STUDIES

CREEP STUDIES OF REFRACTORY METALS AND ALLOYS

- TENSION vs COMPRESSION

- SUBSTRUCTURE CORRELATIONS

MECHANICAL TESTING OF IRIDIUM 
MECHANICAL TESTING OF NEUTRON IRRADIATED MATERIALS

- COMPRESSIVE CREEP

- DYNAMIC ELECTRON MICROSCOPE STUDIES

- SUBSTRUCTURE CORRELATIONS 


\section{MATERIALS RESEARCH}

Selected Bibliography

T. B. Rhinehammer and J. E. Selle, The Effect of High Temperature on the Integrity of Radio-Isotope Heat Source Capsules, MLM-1141 (September 13, 1962).

J. E. Selle, "Application of Metallography to the Study of Phase Equilibria," Symposium on Research at Mound Laboratory June 6-7, 1963, MLM-1163.

D. E. Etter and J. E. Selle, "Metallographic and Differential Therma1 Analysis of the Purity of Cerium," Trans. AIME, 230, 591-595 (1964).

G. W. Powell and J. D. Braun, "Diffusion in the Gold-Indium System," Trans. AIME, 230, 694-9 (1964).

J. E. Selle and D. E. Etter, "The Plutonium-Cerium System," Trans. AIME, 230, 1000-1005 (1964).

T. B. Rhinehammer, D. E. Etter, J. E. Selle and P. A. Tucker, "The Cerium-Copper System," Trans. AIME, 230, 1193-1198 (1964).

J. D. Braun, "Analysis of Complex Inclusions in Steel," Iron and Steel, 60-62 (February 1964).

L. J. Wittenberg, D. E. Etter, J. E. Selle and P. A. Tucker, "Phase Equilibria in the Plutonium-Cerium-Copper System," Nuclear Science and Engineering, 23, 1-7 (1965).

T. B. Rhinehammer, D. E. Etter, J. E. Selle and P. A. Tucker, "The Cerium-Copper System," Monsanto Technical Review, 10, 13-15 (1965).

J. D. Braun and R. J. DeSando, "Identification and Characterizations of Inclusions and Impurities in Commercial High Purity Beryllium," ASM Trans., 58, 105 (1965).

G. L. Downs and J. D. Braun, "Pseudo-Fivefold Symmetry in Carbonyl Process Nicke1," Science, 154:3755, 1443 (1966).

G. L. Downs and J. D. Braun, "The Investigation of Thick Films of Vapor Deposited Aluminum and Gold by Transmission Electron Microscopy," Technical Papers, 2lst Metallographic Group Meeting, USAEC, CONF-670533, p. 192 (1967). 
J. E. Selle, "The Plutonium-Gold System," in Plutonium 1965, A. E. Kay and M. B. Waldron (Eds.), Chapman and Ha11, Ltd., London, 1967, p. 450.

E. W. Johnson, J. R. Wysong and R. E. Zielinski, Plutonium-238 Radioisotope Fueled Life Support System Test, MLM-1431 (February 27, 1968), 39 pp. (C-RD).

J. E. Selle and R. E. Fitzharris, The Compatibility of ${ }^{238} \mathrm{PuO}_{2}$ Microspheres with Refractory Metals and Alloys at $1000^{\circ} \mathrm{C}$ (U), MLM-1502 (May 1, 1968), 15 pp. (C-RD).

G. L. Downs, J. D. Braun and V. D. Jones, "A Technique for Identification of Microquantities of Corrosion Products on Miniaturized Electronic Components," Corrosion, 24:6, 178-9, (1968).

J. E. Selle, R. E. Fitzharris, J. R. McDougal and P. E. Teaney, "Compatibility of Plutonium Fuels with Capsule Materials (U)," presented at the Symposium on Materials for Radioisotope Heat Sources, Gatlinburg, Tenn., October 2-4, 1968 (C-RD).

R. E. Zielinski, "Helium Release from ${ }^{238} \mathrm{PuO}_{2}$ Microspheres Between Ambient Temperatures and $1200^{\circ} \mathrm{C}$," presented at the Recent Findings in Plutonium Research Conference, Los Alamos Scientific Laboratory, Los Alamos, N. M., December 4-5, 1968.

J. E. Selle, A Summary of the Phase Diagrams and Compatibility of $\mathrm{PuO}_{2}$ with Various Materials, MLM-1589, (April 21, 1969), 38 pp.

J. E. Selle, "The Internal Friction of Cobalt," Cobalt, 4 , 186189 (1969).

J. E. Selle and A. E. Focke, "An Internal Friction Study of the Allotropic Transformations of Plutonium, Uranium and Cobalt," J. Nuclear Materials, 33, 149-158 (1969).

M. D. Kelly and J. E. Selle, Metallographic Analys is of the SNAP-19B (IRHS) Capsule (U), MLM-1652 (July 15, 1969), 28 pp.

J. E. Selle and J. J. Rechtien, "Internal Friction of Neptunium," J. Nuclear Materials, 31, 203-210 (1969).

R. E. Zielinski, "Helium Release from ${ }^{3}{ }^{38} \mathrm{PuO}_{2}$ Microspheres," presented at the Helium Release from ${ }^{238} \mathrm{PuO}_{2}$ Review Meeting, AEC Headquarters, Germantown, MD, August 7, 1969. 
G. L. Downs, J. D. Braun, R. C. McWilliams, "Autoradiographic Investigation of Tritium Segregation in Stainless Stee1," Technica1 Papers of 23rd Metallographic Meeting, San Francisco, September, 1969, CONF. 69-0954, USAEC, December 1970, PP. 57-71

G. W. Powe 11 and K. F. Chaney, "Diffusivity of Tritium in 304 Stainless Steel in Temperature Range of 100-300 ${ }^{\circ} \mathrm{C}, "$ Metallurgical Transactions, 1,2356 (1970).

G. W. Powell, J. D. Braun, K. F. Chaney and G. L. Downs, "Solubility and Distribution of Tritium in Annealed and Cold-Worked 304 Stainless Steel in the 100 to $300^{\circ} \mathrm{C}$ Temperature Range," Corrosion, 26:8, 223-228 (1970).

G. W. Powe11, J. D. Braun, K. F. Chaney and G. L. Downs, "Solubility and Distribution of Tritium in Annealed and Cold Worked 304 Stainless Steel in the $100-300^{\circ} \mathrm{C}$ Temperature Range," Corrosion, 28, 223 (1970).

C. J. M. Northrup, Jr., D. E. Amos and R. E. Zielinski, "Helium Diffusion in ${ }^{238} \mathrm{PuO}_{2}$," in Plutonium 1970 and Other Actinides, W. N. Miner (Ed.), Proceedings of the 4th International Conference on Plutonium and Other Actinides, Santa-Fe, New Mexico, October 5-9, 1970, American Institute of Mining, Metallurgical and Petroleum Engineers, Inc., and Los Alamos Scientific Laboratory, Part II, pp. 575-584.

J. D. Braun, K. F. Chaney, G. L. Downs and G. W. Powe11, Solubility of Tritium in Annealed and Cold-Worked Copper, MLM-1734 (January 8, 1971), 6 pp.

J. D. Braun, G. L. Downs and G. W. Powel1, "An Autoradiographic Investigation of Tritium in 304 Stainless Steel," Metallography, 4, 231-242 (1971).

M. D. Kelly and J. E. Selle, "Quantitative Analyṣis of a Cermet Sphere," The Proceedings of the International Metallographic Society, Denver, Colorado, September 21-23, 1971, pp. 213-217.

P. E. Teaney and J. E. Selle, "The Use of a Quantitative Image Analyzer to Determine Microhardness Values," The Proceedings of the Internationa1 Metallographic Society, Denver, Colorado, September 21-23, 1971, pp. 291-301.

C. J. Kershner, Helium Permeation Through Tantalum Meta1, MLM1846 (January 3, 1972), 26 pp. 
R. E. Zielinski and D. E. Etter, Investigation of Supplementary Materials Used in the Pioneer RTGs and Capsule Shipping Containers, MLM-1882 (January 12, 1972), 24 pp.

M. D. Kelly, J. E. Selle, P. E. Teaney, "Applications of Image Analys is to Radioisotopic Fuel Forms," The Microscope, 20, 341352 (1972).

D. E. Etter and W. H. Smith, "Effect of Oxygen Contamination on the Tensile Properties of T-111 (Tantalum-8 Tungsten-2 Hafnium) at $1204^{\circ} \mathrm{C}, " \mathrm{~J}$. Less Common Metals, 27:2, 109-122, (1972).

W. C. Wyder, Hydroforming Metal Foils, MLM-1926 (June 26, 1972), 16 pp.

Mound Laboratory Isotopic Power Fuels Programs: April-June 1972, MLM-1945 (August 31, 1972), pp. 27-39.

Mound Laboratory Isotopic Power Fuels Programs: July-September 1972, MLM-1983 (November 30, 1972), pp. 24-25.

Mound Laboratory Isotopic Power Fuels Programs: October-December 1972, MLM-2014 (January 31, 1973), pp. 21-22.

D. R. Schaeffer, The Effect of Oxygen and Temperature on the Impact Behavior of T-111 (Ta-8\% W-2\% Hf), MLM-2037 (May 1, 1973), $57 \mathrm{pp}$.

Mound Laboratory Isotopic Power Fuels Programs: January-March 1973, MLM-2040 (Apri1 30, 1973), pp. 14-31.

P. E. Teaney and J. J. English, The Effects of Iron and Chromium Fuel Impurities on Molybdenum at $1500^{\circ} \mathrm{C}$ and $1700^{\circ} \mathrm{C}$ and on Tanta lum-10 Wt \% Tungsten at $1200^{\circ} \mathrm{C}$, MLM-2055 (August 24, 1973), $29 \mathrm{pp}$.

R. E. Zielinski and V. K. Sikka, "Electroplating of Iridium Foils for Transmission Electron Microscopy," J.Less Common Meta1s, 31, 393 (1973).

J. D. Braun and G. W. Powe11, "Reaction Diffusion and Associated Non-Equilibrium Effects in the Au-Co System," Met. Trans., 4, 1207-1212 (1973).

Mound Laboratory Isotopic Power Fuels Programs: July-September 1973, MLM-2099 (November 21, 1973), pp. 24-39. 
Helium Diffusion and Tritium Effluent Control

MOUND LABORATORY • MONSANTO RESEARCH CORPORATION • MIAMISBURG, OHIO 


\section{AN ADV ANCED TECHNOLOGY PROJECT WAS INITIATED IN 1972 TO ACHIEVE LONG RANGE GOALS FOR REDUCING TRITIUM EMISSIONS}

- Facility Evaluation

- Basic Decontamination \& Concentration Technology

- Complete Processes \& Systems

- High Sensitivity Monitoring Instrumentation 


\section{THERE IS A WIDE VARIATION IN QUANTITY AND CONTAMINATION LEVEL OF MOUND'S GASEOUS EFFLUENTS}

CLASS SOURCE

1.9

II.g

III.g
G. B.

Room

Stack
CONCENTRATION

$\left(\mathrm{Ci}_{\mathrm{i}} / \mathrm{m}^{3}\right)$

1.100

$\sim 4 \times 10^{-5}$

$-1 \times 10^{-5}$
HTO

(\%)

1.10

$-$

$10-90$ 


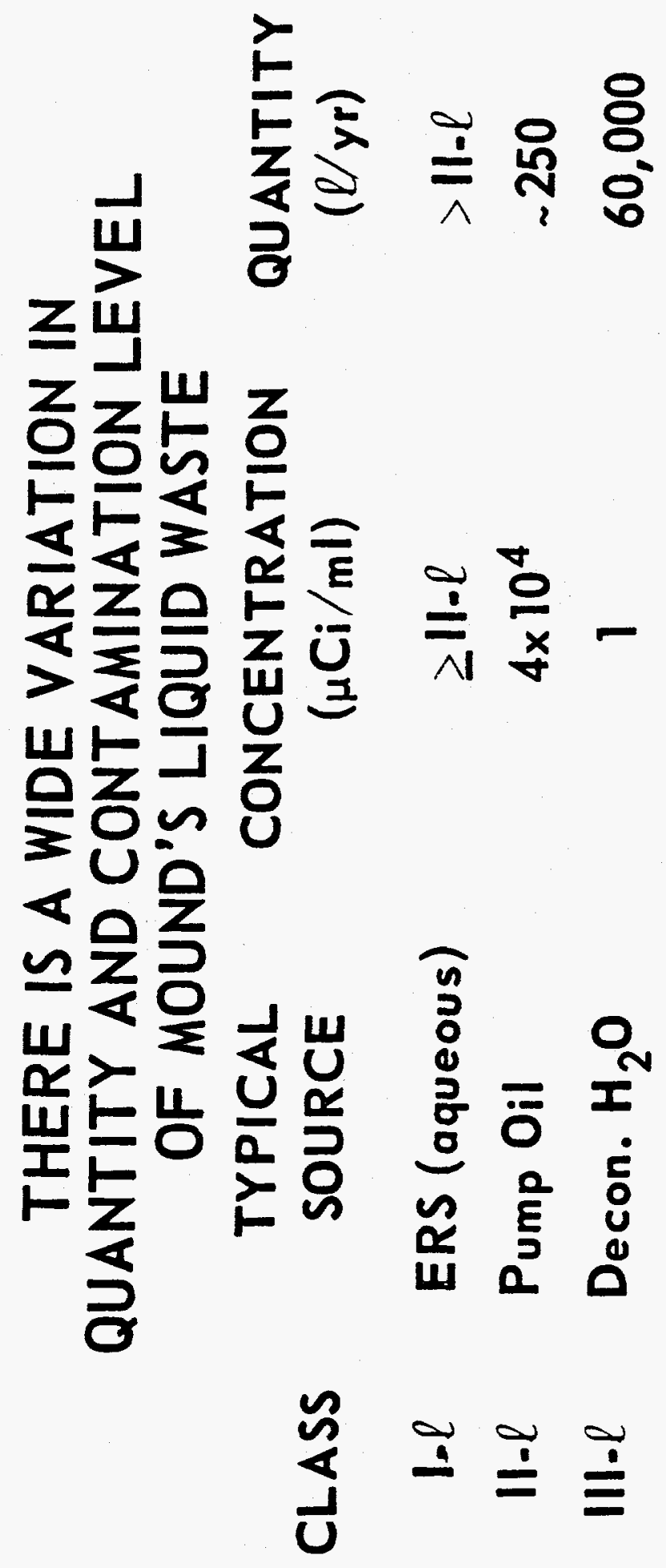




\section{EXPERIMENTAL WORK IS IN PROGRESS ON DECONTAMINATION TECHNOLOGY BASED ON:}

- Cryogenic Adsorption (Class l-g)

- Getters (Class I-g)

- Extractive Distillation (Class III- $\ell$ )

- Molecular Excitation (Class III- $\ell$ )

- Catalytic Oxidation/Adsorption (ERS, ECS, Class I \& II-g) 


\section{CRYOGENIC PROCESS SCHEMATIC FOR TRITIUM CONTROL IN GLOVEBOX ATMOSPHERE SYSTEMS}

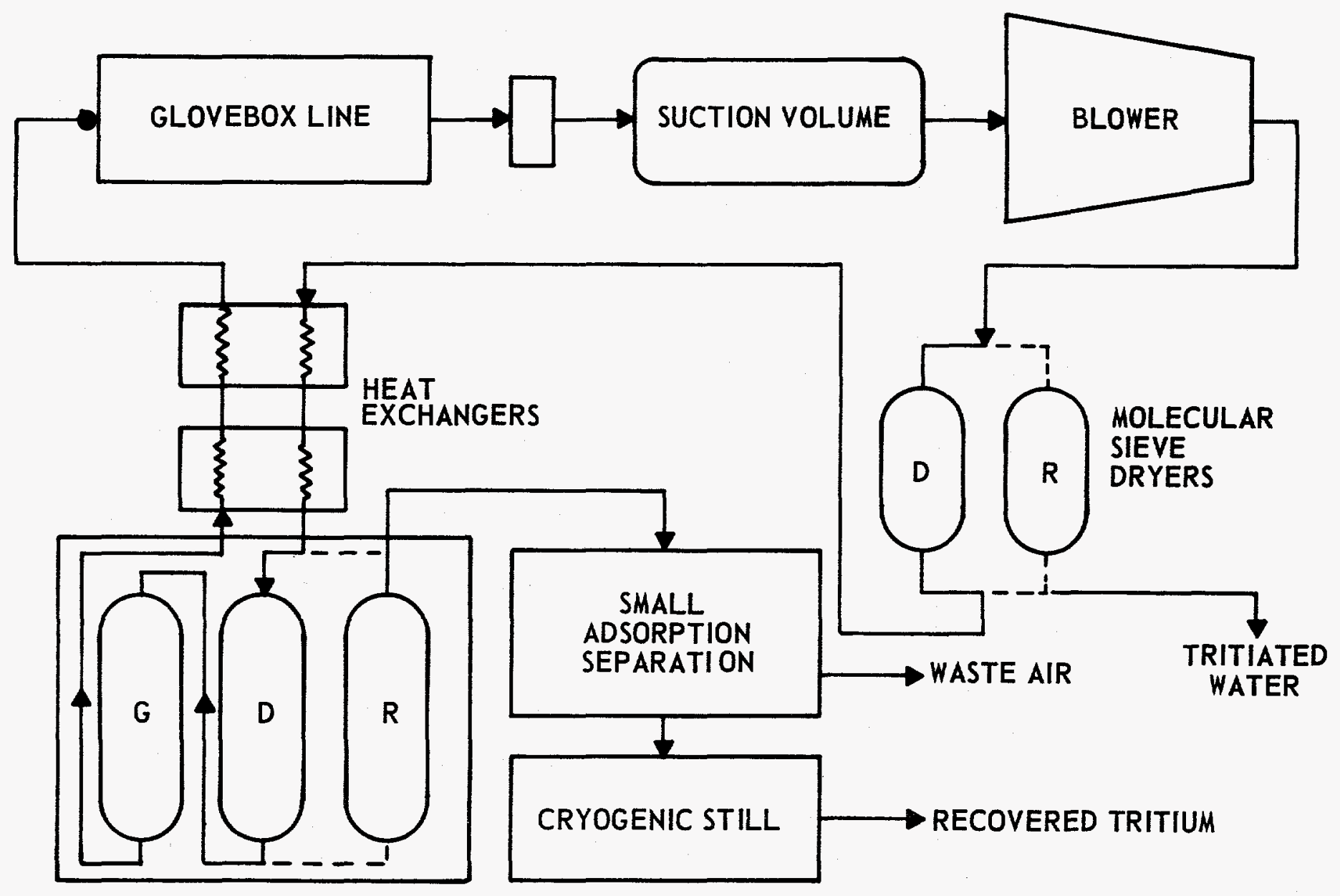




\section{SYSTEM SCHEMATIC FOR EMERGENCY CONTAINMENT OF TRITIUM}

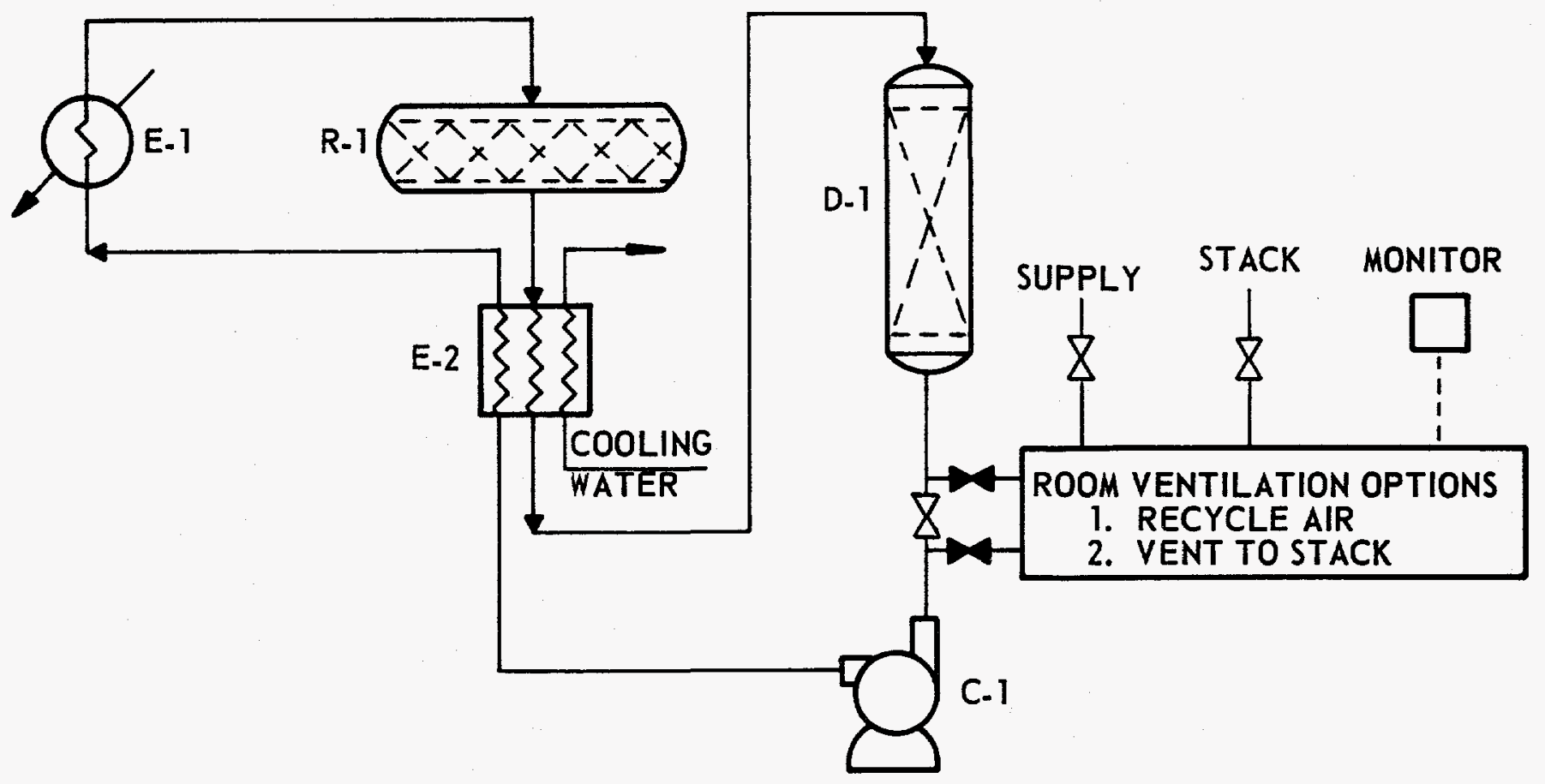



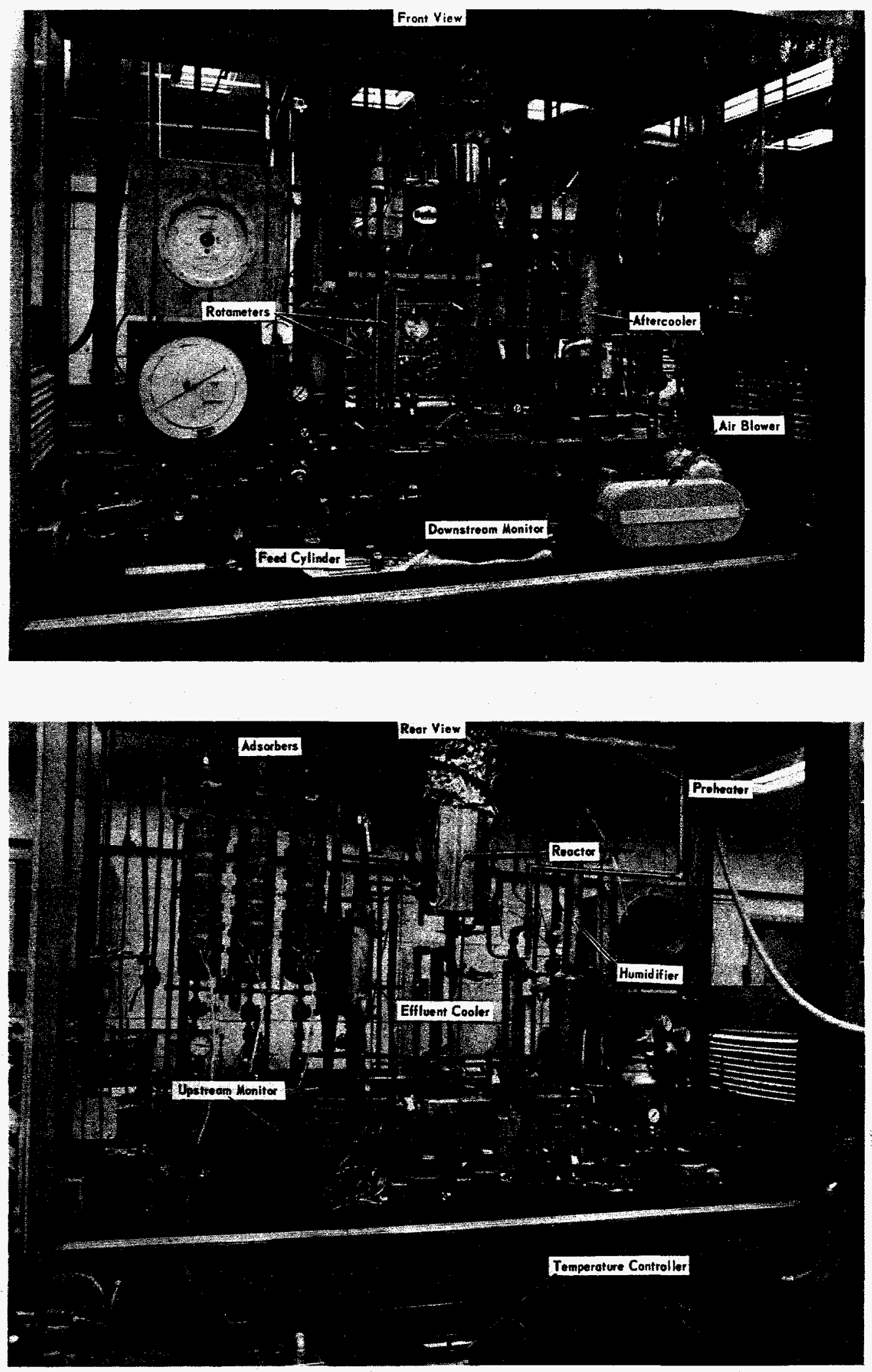


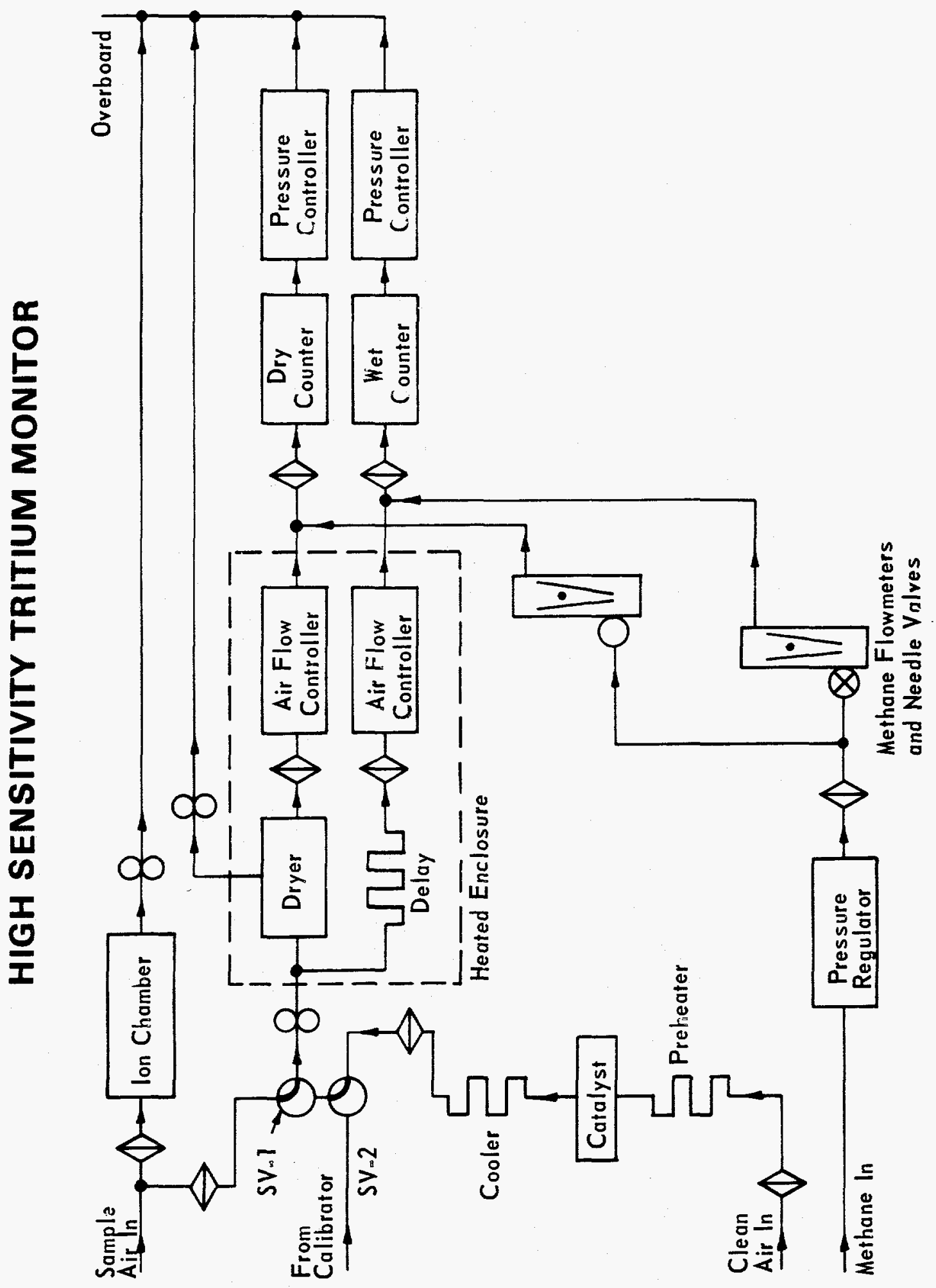




\section{EXPERIMENTAL WORK IS IN PROGRESS ON RECOVERY TECHNOLOGY BASED ON: \\ - Cryogenic Distillation (Gas) \\ - Pd Column Separation (Gas) \\ - Fuel Cell/Electrolysis (Liquid) \\ - Chemical Decomposition (Liquid)}


THE "TECL" DESIGN IS BASED
ON A CLOSED ${ }^{3}$ H CYCLE CONCEPT

$<10 \%$ RCG AT STACK

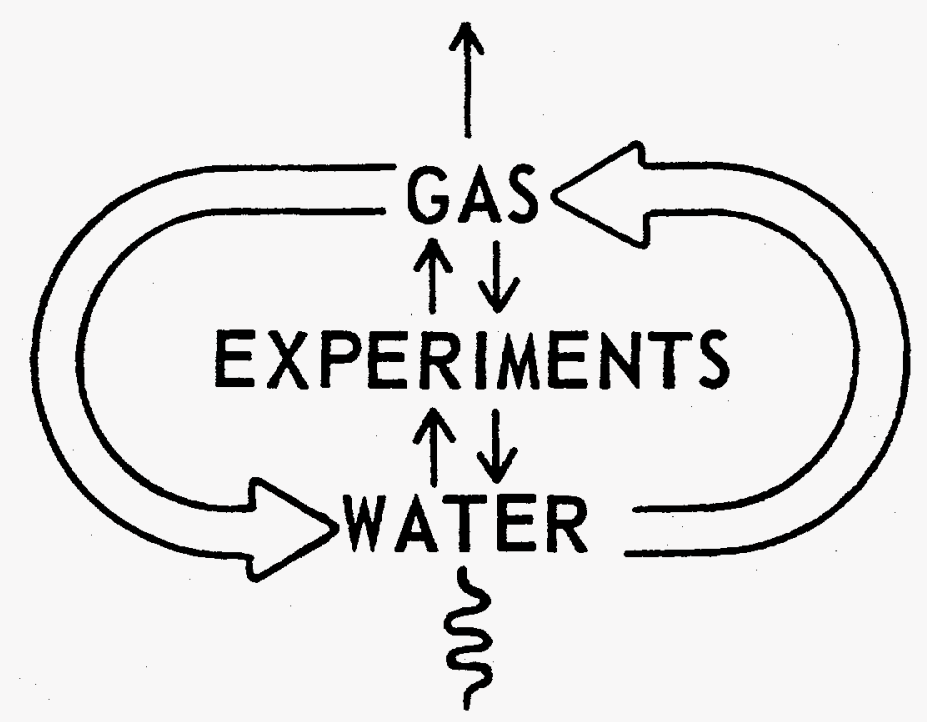

ZERO AQUEOUS WASTES 
TRITIUM EFFLUENT CONTROL LABORATORY

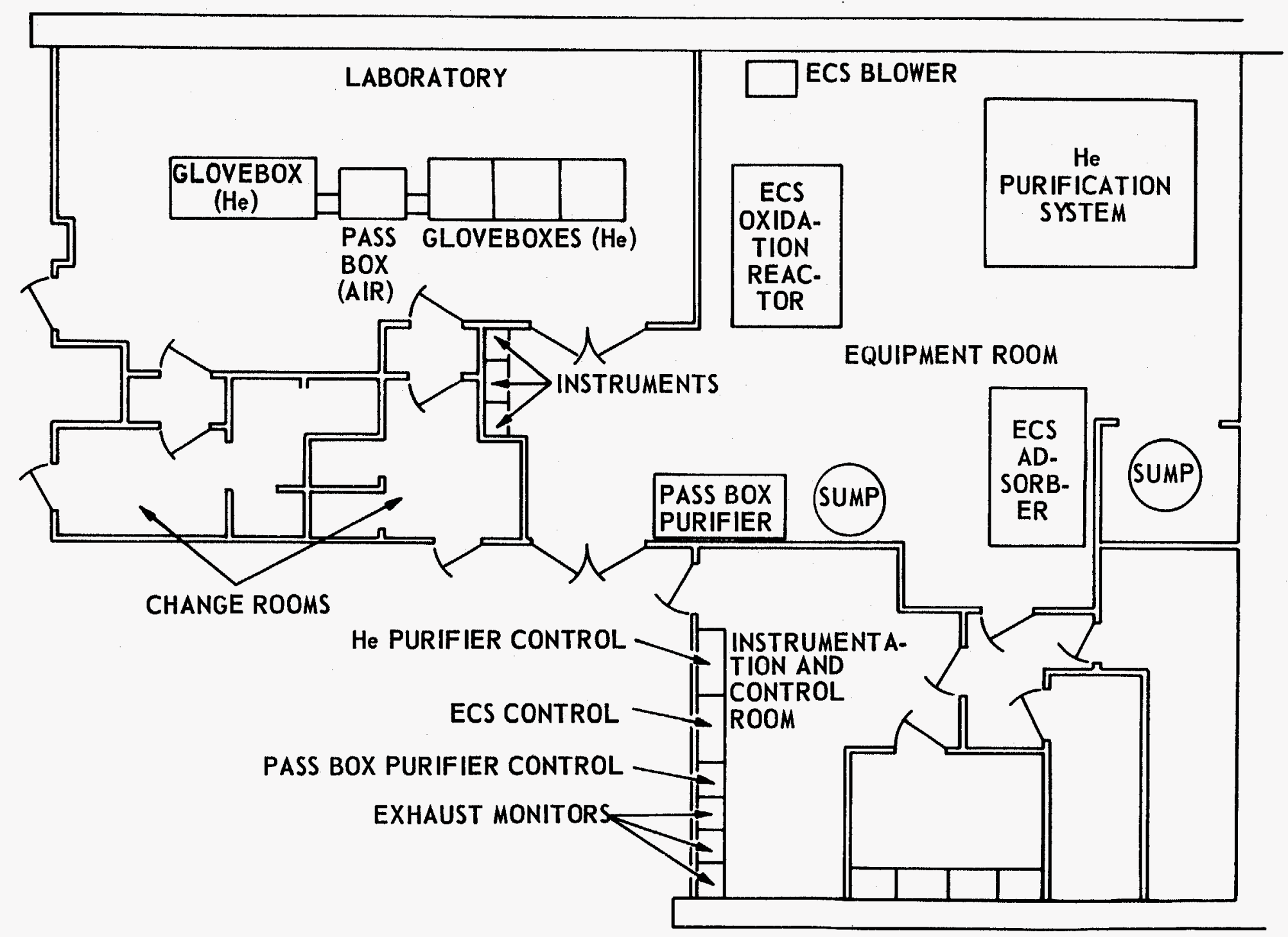




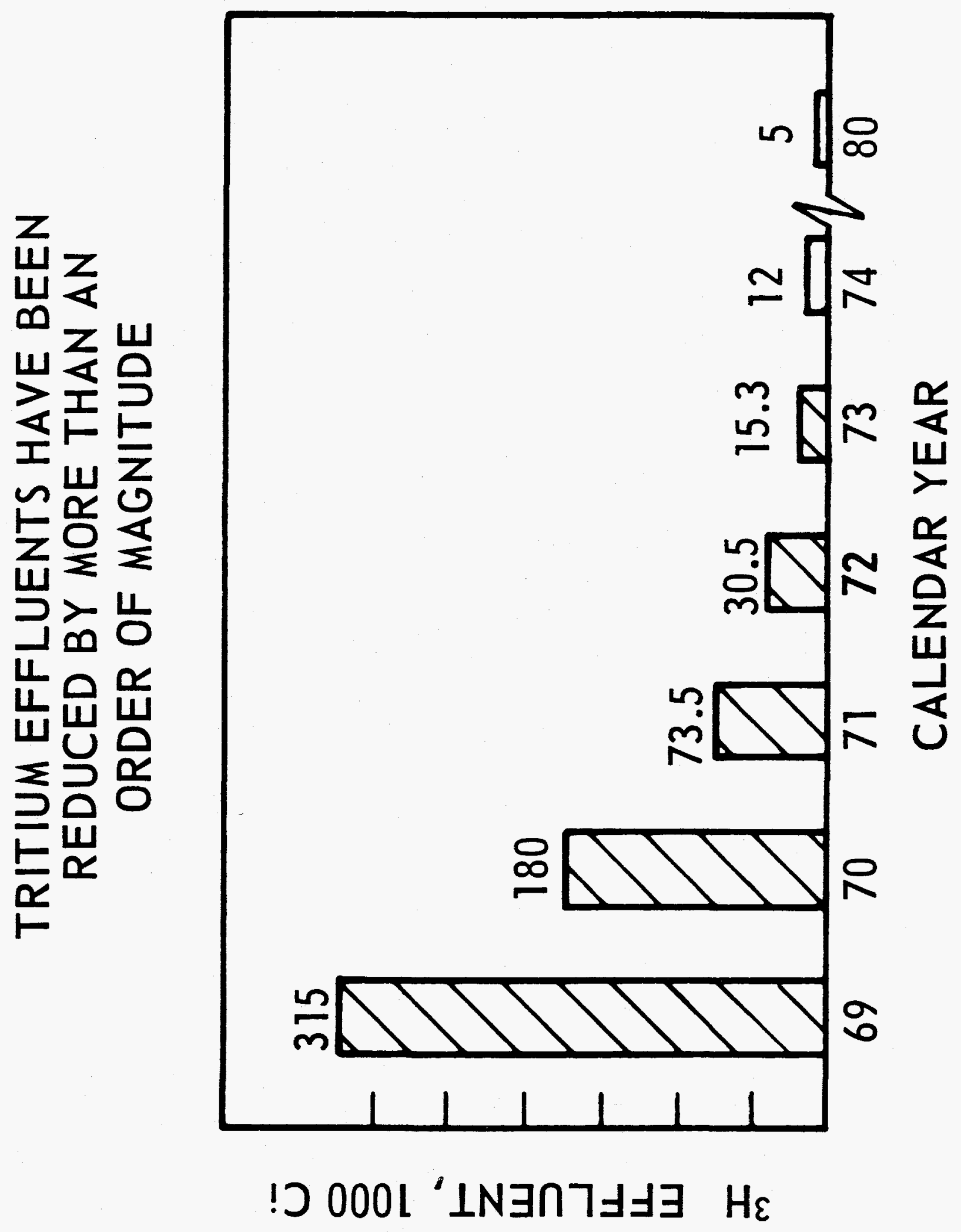


A VARIETY OF HELIUM DEPOSITION \& MIGRATION STUDIES HAVE BEEN CARRIED OUT AT MOUND

- ${ }^{4} \mathrm{He}$ IN ${ }^{238} \mathrm{PuO}_{2}$ (a DECAY IMPLANTED)

- ${ }^{4}$ He PERMEATION THROUgh TANTALUM

- ${ }^{3} \mathrm{He}$ IN TANTALUM ( $T_{2}$ DECAY IMPLANTED) 


\section{A HIGH SENSITIVITY QUADRUPOLE MASS SPECTROMETER SYSTEM HAS BEEN DEVELOPED FOR He DIFFUSION STUDIES}

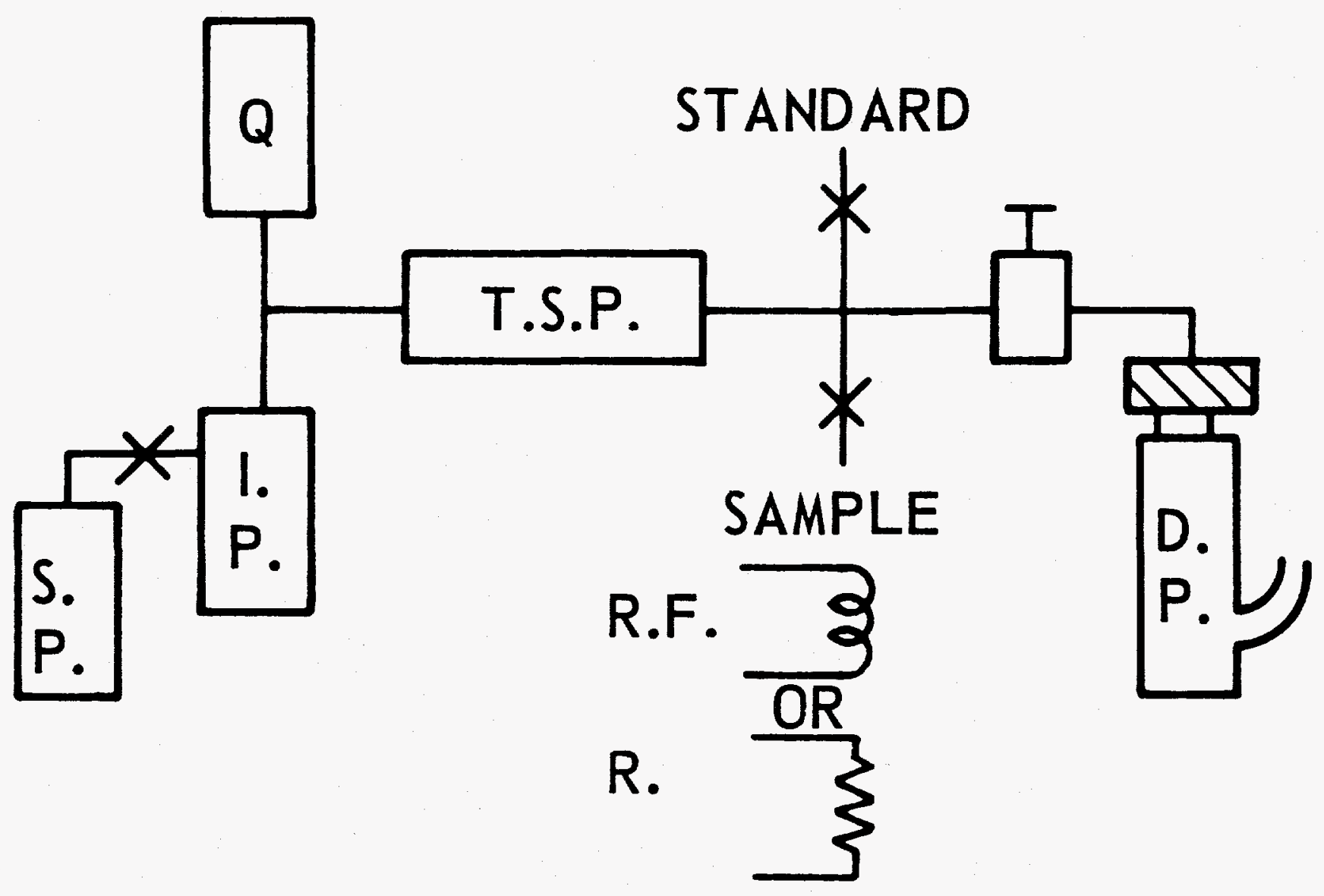


PERMEABILITY OF He THROUGH TANTALUM METAL HAS BEEN DEMONSTRATED AND A MECHANISM POSTULATED
VACANCY
INT.
MEAS.
$Q_{p}$
202
110
100
D $6 \times 10^{-11}$
$1 \times 10^{-6}$
$3 \times 10^{-6}$
$S \quad 1 \times 10^{6}$
$1 \times 10^{10}<3 \times 10^{8}$
P $\quad 9 \times 10^{-5}$
$1 \times 10^{4}$
$1 \times 10^{3}$ 
HELIUM DIFFUSION AND TRITIUM EFFLUENT CONTROL

\section{Selected Bibliography}

B. J. Hannahs and C. J. Kershner, Bibliography on Handling, Control and Monitoring of Tritium (December 1968-January 1972), MLM-1946 (September 5, 1972), 44 pp.

C. J. Kershner and T. Ben Rhinehammer, "Tritium Effluent Control Program at Mound Laboratory," Proceedings of AEC Pollution Control Conference, Oak Ridge, Tennessee, CONF721030, pp. 408-454 (1973).

T. B. Rhinehammer and P. H. Lamberger, Tritium Control Technology, WASH-1269 (December 1973), $530 \mathrm{pp}$.

J. C. Bixel and C. J. Kershner, "A Study of Catalytic Oxidation and Oxide Adsorption for the Removal of Tritium from Air," to be published.

T. B. Rhinehammer, "Techniques and Facilities for Handling and Packaging Tritiated Liquid Wastes," to be published.

D. G. Carfagno and W. H. Westendorf, Environmental Monitoring Report: July-December 1971 and 1971 Summary, MLM-1922 (May 22, 1972), 41 pp.

C. J. Kershner, Helium Permeation Through Tantalum Metal, MLM-1846 (January 3, 1972), 26 PP.

W. E. Sheehan, Ruggedized Ultrasensitive Field Air Sampler for Differentially Determining Tritium Oxide and Gas in Ambient Air Atmosphere, MLM-2015 (April 6, 1973), 22 pp. 